The Free Internet Journal for Organic Chemistry
Paper

Arkivoc 2018, part v, 0-0

to be inserted by editorial office

\title{
Diastereoselective synthesis of 2-vinylpyrrolidines and 2-vinylpiperidines by the palladium-catalysed cyclization of amino-allylic carbonates containing a chiral protecting group
}

\author{
Beata Olszewska, Aleksandra Jabłońska, and Anna Zawisza* \\ Department of Organic and Applied Chemistry, University of Łódź, Tamka 12, 91-403 Łódź, Poland \\ Email: azawisza@chemia.uni.lodz.pl
}

Received 04-05-2018

Accepted $05-21-2018$

Published on line $07-02-2018$

\section{Abstract}

An efficient diastereoselective synthesis of pyrrolidine- and piperidine-type N-heterocycles is reported, by the intramolecular $\mathrm{Pd}(0)$-catalysed cyclization of amino carbonates containing chiral protecting group. The use of chiral auxiliary in the cyclization gave the corresponding heterocyclic derivatives in excellent yields and with good dr values.

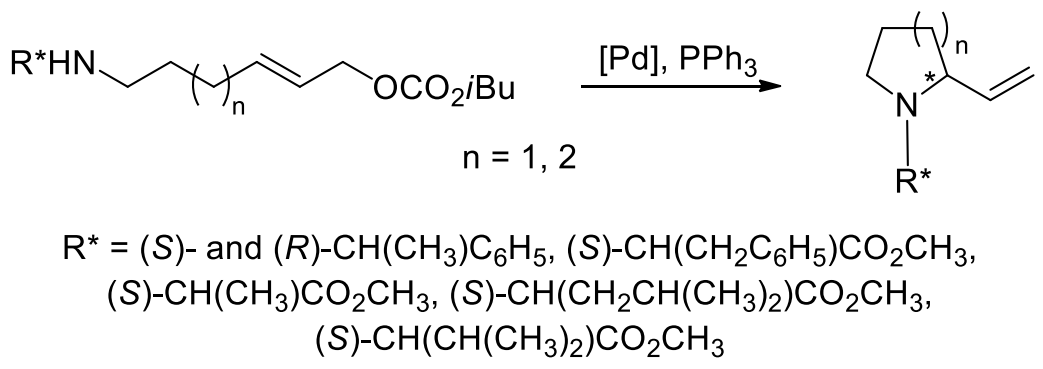

Keywords: Allylic carbonates, cyclization, homogeneous catalysis, nitrogen heterocycles, palladium 


\section{Introduction}

Saturated nitrogen heterocycles, such as pyrrolidines and piperidines, often possess potent biological activity and are therefore of interest for organic and medicinal chemists. ${ }^{1-4}$ For example, piperidine alkaloids are known pharmaceuticals; (-)-prospinine ${ }^{5}$ is used as an anesthetic and analgesic, (-)-spectaline ${ }^{6}$ has cytotoxic activity and (-)-cassine ${ }^{7}$ has antifungal activity. There are many drugs, especially with piperidine rings, for example the well-known Donepezil which has been shown to be well tolerated to improve cognition and global function in patients with mild to moderately severe Alzheimer's disease. ${ }^{8-9}$

On the other hand, these heterocyclic derivatives play an important role in organic synthesis as excellent building blocks for further synthesis. N-Substituted cyclic derivatives containing a vinyl moiety are useful starting materials for olefin cross-metathesis reactions ${ }^{10}$ and also excellent intermediates to afford medium and large-ring cyclic structures by 3 -aza-Cope rearrangements. ${ }^{11}$

For these reasons, the efficient synthesis of optically active pyrrolidine and piperidine derivatives has been of long-standing interest. Several powerful new transformations have been developed that involve the use of $\mathrm{Pd}$-catalysed $\mathrm{C}-\mathrm{N}$ bond-forming reactions for construction of heterocyclic rings. This type of transformation frequently occurs under mild conditions, tolerates a broad array of functional groups, and proceeds with high stereoselectivity. ${ }^{12-34}$

Extending our previous work on the use of allylic carbonates in the synthesis of $\mathrm{O}$ - and $\mathrm{N}$-heterocycles, ${ }^{35-40}$ in this paper we report new results on diastereoselective intramolecular $\mathrm{Pd}(0)$-catalysed allylic aminations. Herein, we present the first examples of asymmetric palladium catalysis in which the starting amino carbonates contain a chiral protecting group with known and specified absolute configuration which can act as a chiral auxiliary and also enable one to perform the cyclization reaction in a stereoselective way, without the presence of any chiral ligands.

\section{Results and Discussion}

\section{Synthesis of the starting materials}

The starting allylic carbonates $\mathbf{5 a - j}$ (Scheme 1 ) were prepared by reduction of bromoesters $\mathbf{1} \mathbf{a}, \mathbf{b}$ to the corresponding aldehydes, ${ }^{41}$ followed by elongation of the chain via the Wittig rection, ${ }^{42}$ reduction to the alcohol $\mathbf{3 a}, \mathbf{b},{ }^{43}$ condensation with isobutyl chloroformate as described previously ${ }^{37,40}$ and finally, the reaction of received bromo-derivatives $\mathbf{4} \mathbf{a}, \mathbf{b}$ with the appropriate amines ((S)-1-phenylethanamine and $(R)$-1phenylethanamine) or amino acid ester hydrochlorides, obtained by the procedure described in the literature (derivatives of L-phenylalanine, L-alanine, L-leucine and L-valine). ${ }^{4-47}$ This procedure allows us to prepare carbonates (5a-j) containing chiral amino protecting group in good yields (21-66\%). 

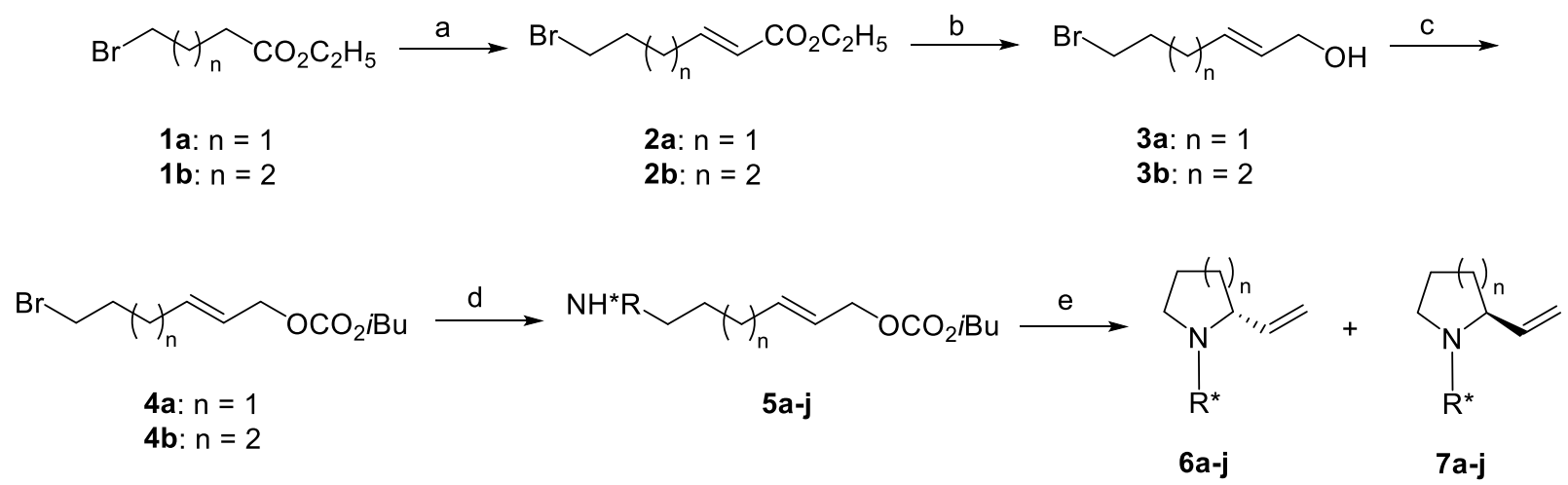

$$
\begin{aligned}
& \text { a: } \mathrm{n}=2, \mathrm{R}^{*}=(\mathrm{S})-\mathrm{CH}\left(\mathrm{CH}_{3}\right) \mathrm{C}_{6} \mathrm{H}_{5} \\
& \text { b: } \mathrm{n}=2, \mathrm{R}^{*}=(R)-\mathrm{CH}\left(\mathrm{CH}_{3}\right) \mathrm{C}_{6} \mathrm{H}_{5} \\
& \text { c: } \mathrm{n}=2, \mathrm{R}^{*}=(S)-\mathrm{CH}\left(\mathrm{CH}_{2} \mathrm{C}_{6} \mathrm{H}_{5}\right) \mathrm{CO}_{2} \mathrm{CH}_{3} \\
& \text { d: } \mathrm{n}=1, \mathrm{R}^{*}=(S)-\mathrm{CH}\left(\mathrm{CH}_{2} \mathrm{C}_{6} \mathrm{H}_{5}\right) \mathrm{CO}_{2} \mathrm{CH}_{3} \\
& \text { e: } \mathrm{n}=1, \mathrm{R}^{*}=(S)-\mathrm{CH}\left(\mathrm{CH}_{3}\right) \mathrm{CO}_{2} \mathrm{CH}_{3}
\end{aligned}
$$$$
\text { f: } \mathrm{n}=2, \mathrm{R}^{*}=(\mathrm{S})-\mathrm{CH}\left(\mathrm{CH}_{3}\right) \mathrm{CO}_{2} \mathrm{CH}_{3}
$$$$
\text { g: } n=1, \mathrm{R}^{*}=(\mathrm{S})-\mathrm{CH}\left(\mathrm{CH}_{2} \mathrm{CH}\left(\mathrm{CH}_{3}\right)_{2}\right) \mathrm{CO}_{2} \mathrm{CH}_{3}
$$$$
\text { h: } \mathrm{n}=2, \mathrm{R}^{*}=(\mathrm{S})-\mathrm{CH}\left(\mathrm{CH}_{2} \mathrm{CH}\left(\mathrm{CH}_{3}\right)_{2}\right) \mathrm{CO}_{2} \mathrm{CH}_{3}
$$$$
\text { i: } n=1, \mathrm{R}^{*}=(\mathrm{S})-\mathrm{CH}\left(\mathrm{CH}\left(\mathrm{CH}_{3}\right)_{2}\right) \mathrm{CO}_{2} \mathrm{CH}_{3}
$$$$
\text { j: } \mathrm{n}=2, \mathrm{R}^{*}=(\mathrm{S})-\mathrm{CH}\left(\mathrm{CH}\left(\mathrm{CH}_{3}\right)_{2}\right) \mathrm{CO}_{2} \mathrm{CH}_{3}
$$

reagents and conditions: (a) 1. DIBAL-H, $\mathrm{CH}_{2} \mathrm{Cl}_{2},-78{ }^{\circ} \mathrm{C}$, 2. $\mathrm{Ph}_{3} \mathrm{P}=\mathrm{CHCO}_{2} \mathrm{C}_{2} \mathrm{H}_{5}, \mathrm{CH}_{2} \mathrm{Cl}_{2}$, rt; (b) DIBAL-H, Et ${ }_{2} \mathrm{O}, 0^{\circ} \mathrm{C}$; (c) $\left(\mathrm{CH}_{3}\right)_{2} \mathrm{CHCH}_{2} \mathrm{OCOCl}, \mathrm{C}_{5} \mathrm{H}_{5} \mathrm{~N}, \mathrm{CH}_{2} \mathrm{Cl}_{2}, 0^{\circ} \mathrm{C} \rightarrow \mathrm{rt}$; (d) $\mathrm{RNH}_{2}, i-\mathrm{Pr}_{2} \mathrm{EtN}, \mathrm{DMF}$, rt for $5 \mathrm{a}, \mathbf{b}$ and $\mathrm{RNH}_{2} \cdot \mathrm{HCl}, \mathrm{K}_{2} \mathrm{CO}_{3}, \mathrm{CH}_{3} \mathrm{CN}, 40{ }^{\circ} \mathrm{C}$ for $5 \mathrm{c}-\mathrm{j}$; (e) [Pd], ligand, solvent.

Scheme 1. $\mathrm{Pd}^{0}$-Catalysed synthesis of heterocycles $6 \mathbf{a}-\mathbf{j}$.

\section{$\mathbf{P d}^{0 / 11-}$-Catalysed cyclisation of the allylic carbonates $\mathbf{5 a , b}$}

The cyclization was first studied with isobutyl carbonate 5 a as the substrate (Scheme 1 ) in THF at $0{ }^{\circ} \mathrm{C}$ in the presence of a catalytic amount of $\mathrm{Pd}_{2}(\mathrm{dba})_{3}$ and $\mathrm{PPh}_{3}$. The course of the reaction was monitored by TLC analysis. After 24 hours in the reaction mixture only the starting compound was observed. The cyclization of carbonate $\mathbf{5 b}$ under these conditions also did not take place (Table 1, Entries 1-2). When the cyclization of $\mathbf{5 a}$ was performed at room temperature, piperidine 7a was obtained as the single stereoisomer in $94 \%$ yield (Table 1, Entry 3), whereas the starting amino carbonate $\mathbf{5 b}$ containing a chiral protecting group with an opposite absolute configuration, gave the cyclization product $\mathbf{6 b}$ containing a reverse configuration at the newly created stereogenic center (Table 1, Entry 4).

Table 1. $\mathrm{Pd}^{0}$-catalysed allylic cyclization of substrates $\mathbf{5 a - b}$ according to Scheme $1^{\mathrm{a}}$

\begin{tabular}{ccccccc}
\hline Entry & Carbonate & {$[\mathrm{Pd}]$} & Ligand & $\mathrm{T}\left[{ }^{\circ} \mathrm{C}\right]$ & ${\text { Yield }(\mathbf{6}+\mathbf{7})[\%]^{\mathrm{b}}}$ & $\mathrm{dr}^{\mathrm{c}}(\mathbf{6 : 7})$ \\
\hline 1 & $\mathbf{5 a}$ & $\mathrm{Pd}_{2} \mathrm{dba}_{3}$ & $\mathrm{PPh}_{3}$ & 0 & traces & - \\
2 & $\mathbf{5 b}$ & $\mathrm{Pd}_{2} \mathrm{dba}_{3}$ & $\mathrm{PPh}_{3}$ & 0 & traces & - \\
3 & $\mathbf{5 a}$ & $\mathrm{Pd}_{2} \mathrm{dba}_{3}$ & $\mathrm{PPh}_{3}$ & 20 & 94 & $0: 100$ \\
4 & $\mathbf{5 b}$ & $\mathrm{Pd}_{2} \mathrm{dba}_{3}$ & $\mathrm{PPh}_{3}$ & 20 & 95 & $100: 0$ \\
5 & $\mathbf{5 a}$ & $\mathrm{Pd}_{2} \mathrm{dba}_{3}$ & $\mathrm{PPh}_{3}$ & 60 & $0^{\mathrm{d}}$ & - \\
6 & $\mathbf{5 b}$ & $\mathrm{Pd}_{2} \mathrm{dba}_{3}$ & $\mathrm{PPh}_{3}$ & 60 & 0 & - \\
7 & $\mathbf{5 a}$ & $\mathrm{Pd}_{2} \mathrm{dba}_{3}$ & $\mathrm{dppb}^{\mathrm{d}}$ & 20 & 99 & $0: 100$ \\
8 & $\mathbf{5 b}$ & $\mathrm{Pd}_{2} \mathrm{dba}_{3}$ & $\mathrm{dppb}$ & 20 & 99 & $100: 0$ \\
9 & $\mathbf{5 a}$ & $\left.\left[\mathrm{PdCl}_{3} \mathrm{C}_{3} \mathrm{H}_{5}\right)\right]_{2}$ & $\mathrm{PPh}_{3}$ & 20 & 0 & - \\
10 & $\mathbf{5 b}$ & $\left.\left[\mathrm{PdCl}_{2} \mathrm{C}_{3} \mathrm{H}_{5}\right)\right]_{2}$ & $\mathrm{PPh}_{3}$ & 20 & 0 & - \\
\hline
\end{tabular}

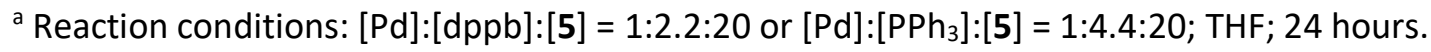

${ }^{\mathrm{b}}$ Isolated product. $\quad{ }^{\mathrm{C}}$ Determined by ${ }^{1} \mathrm{H}$ NMR analysis. ${ }^{\mathrm{d}}$ Decomposition products. 
The same reactions at $60{ }^{\circ} \mathrm{C}$ afforded only difficult to identify decomposition products (Table 1, Entries 56). When the cyclization reaction of carbonates $\mathbf{5} \mathbf{a}$ and $\mathbf{5} \mathbf{b}$ was performed in the presence of $\mathbf{d p p b}$, piperidines $7 \mathbf{a}$ and $\mathbf{6 b}$ were obtained as a single stereoisomer in excellent yields - 99\% (table 1, Entries 7-8). We also investigated the effect of the palladium precursor on this reaction but the cyclization products were not observed with the use of the allylpalladium chloride dimer and $\mathrm{PPh}_{3}$ (Table 1, Entries 9-10).

To determine the relative configuration of the obtained stereoisomers, the cyclisation products $7 \mathbf{a}$ and $\mathbf{6 b}$ were hydrogenolysed in the presence of Pearlman's catalyst $\mathrm{Pd}(\mathrm{OH})_{2} / \mathrm{C}$, to give 2-ethylpiperidine in a quantitative yield. In order easily to handle these compounds of high volatility, the crude reaction mixture was treated with a saturated solution of $\mathrm{HCl}$ to afford hydrochloride salts $\mathbf{8}$ and $\mathbf{9}$ (Scheme 2).

The ${ }^{1} \mathrm{H}$ NMR spectroscopic data and optical rotation for 8 were in excellent agreement with those reported previously for (-)-(2R)-2-ethylpiperidine hydrochloride $\left\{[\alpha]_{\mathrm{D}}^{20}-1.38\left(c\right.\right.$ 0.5, MeOH); lit. ${ }^{48}[\alpha]_{\mathrm{D}}^{20}-1.42(c$ 1.8, $\mathrm{MeOH}$ ), lit. $\left.{ }^{49}[\alpha]_{\mathrm{D}}^{20}-1.2(c 0.2, \mathrm{EtOH})\right\}$. In turn, the optical rotation for 9 was +1.29 (c $\left.0.5, \mathrm{MeOH}\right)$, which unambiguously indicates on the (+)-(2S)-2-ethylpiperidine hydrochloride, and hence $(R)$-absolute configuration in the piperidine ring of $\mathbf{6 b}$.

The received results indicate that the cyclization products $7 \mathbf{a}$ and $\mathbf{6 b}$ have opposite configuration in the piperidine ring, and the stereogenic center located on the $\mathrm{N}$-protecting group of carbonates $\mathbf{5 a}$ and $\mathbf{5 b}$ has a decisive influence on the stereochemical result of the cyclization reaction.

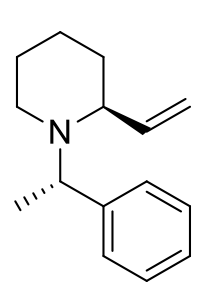

(2S)-7a

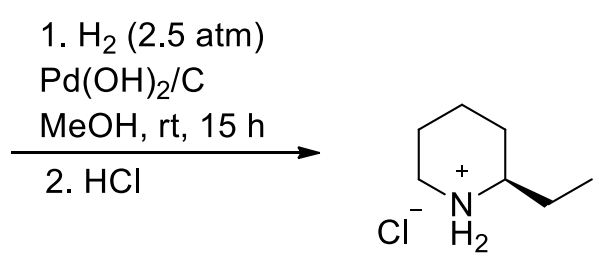

$(2 R)-8$

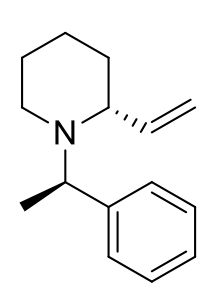

$(2 R)-6 b$

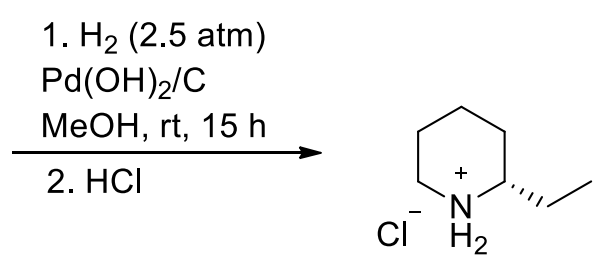

(2S)-9

Scheme 2. Hydrogenolysis reaction of $7 a$ and $7 \mathbf{b}$.

To explain the observed results, we would propose as follows: (i) a six-membered transition state type "chair" for the cyclization reaction, and that the substituents on the nitrogen atom and on the $C(2)$ carbon atom are located in pseudo-axial or pseudo-equatorial positions in a transition state, (ii) a large volume of the substituent on the nitrogen atom enforces their equatorial orientation (Figure1, la and Ila).

For the equatorial position of the $\mathrm{N}$-nitrogen substituent there are two possible orientations of the vinyl substituent at the $\mathrm{C}(2)$ carbon atom (Figure 1, la and Ila). However, there is a strong repulsion between the vinyl moiety in axial position at $\mathrm{C}(2)$, and equatorial nitrogen substituent (Figure 1, Ila), and therefore the equatorially location of vinyl group (Figure 1, la) is strongly favored resulting in the formation of $S$ product exclusively. The mirror image of la must be favored for $\mathbf{5 b}$ with $(R)$-configuration (Figure $\mathbf{1}, \mathbf{I l l a})$. The products $7 \mathrm{a}$ and $\mathbf{6 b}$ are therefore enantiomers to each other, which is confirmed by opposite values of optical rotation and the identical ${ }^{1} \mathrm{H}$ and ${ }^{13} \mathrm{C}$ NMR spectra recorded for these piperidine derivatives. 


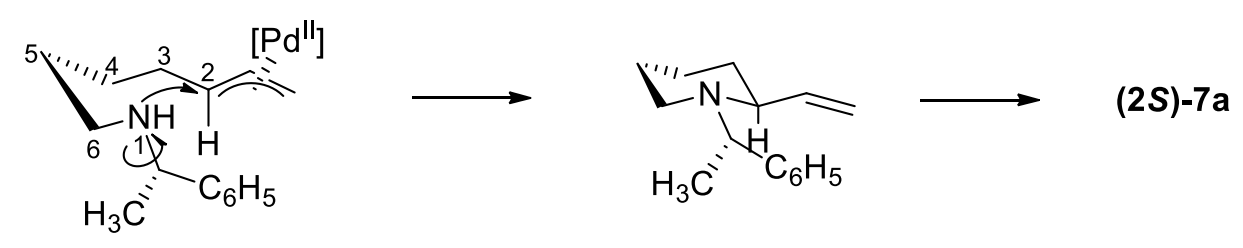

la: favored
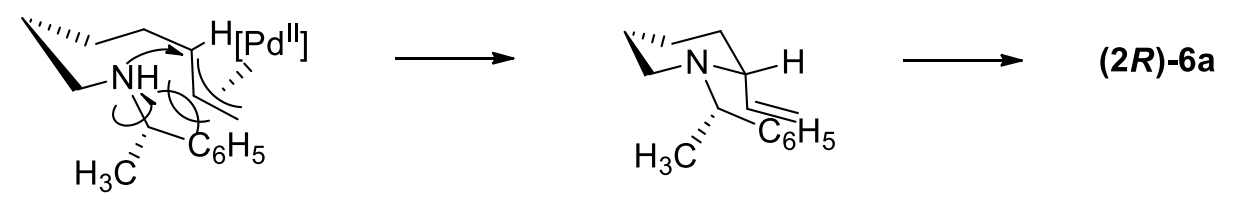

Ila: disfavored

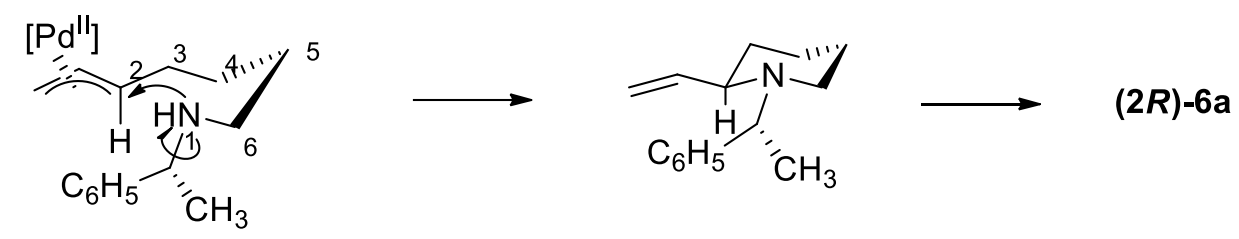

IIla: favored

Figure 1. Models for $\mathrm{Pd}^{0}$-catalysed cyclization of $\mathbf{5 a - b}$.

In the case of the axial orientation of the nitrogen substituent, there is a strong 1,3-diaxal repulsion with a hydrogen atom at $\mathrm{C}(5)$ regardless of the orientation (axial or equatorial) of the remaining substituents (Figure 2, IVa and $\mathbf{V a}$ ). These interactions allows to exclude transition states with axial orientation of substituents on the nitrogen atom.

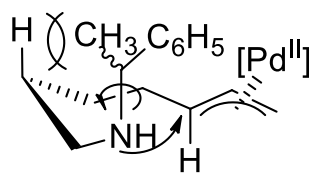

IVa:disfavored

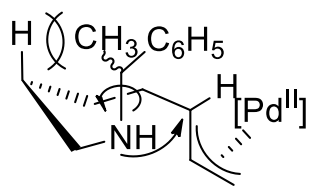

Va:disfavored
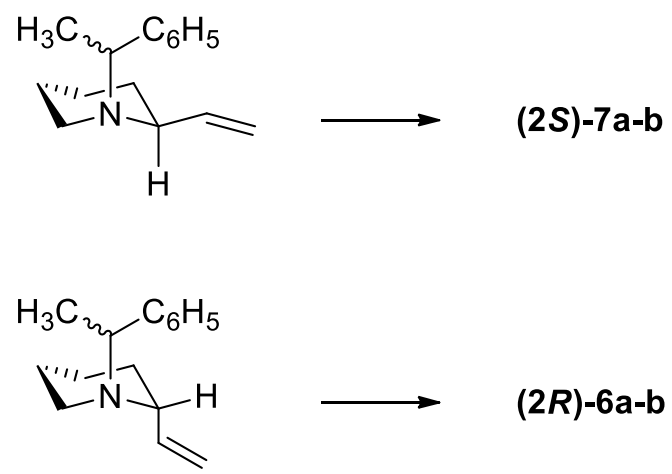

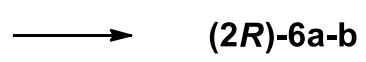

Figure 2. Models for $\mathrm{Pd}^{0}$-catalysed cyclization of $\mathbf{5 a - b}$.

Taking in to account above, we can concluded that, the orientation of the substituents on the $\mathrm{C}(2) \mathrm{carbon}$ atom determines the product configuration and the equatorial location of the N-protecting group allows the aforementioned cyclisation.

\section{$\mathbf{P d}^{0}$-Catalysed cyclization of the allylic carbonates $5 \mathrm{c}-\mathrm{j}$}

Encouraged by the positive results for the carbonates $\mathbf{5 a}$ and $\mathbf{5 b}$ we decided to carry out the cyclization of the other carbonates containing chiral amino protecting group (5c-j). As the first, we chose a L-phenylalanine 
derivative $\mathbf{5 c}$ (Table 2 ). The reaction performed in tetrahydrofuran at room temperature in the presence of a catalytic amount of $\mathrm{Pd}_{2} \mathrm{dba}_{3} / \mathrm{dppb}$ gave a separable mixture of piperidines $6 c$ and $7 \mathrm{c}$ in a $45: 55$ ratio and in 99\% overall yield (Table 2, Entry 1). Reaction with dppe as the ligand afforded $6 \mathbf{c}$ and $7 \mathrm{c}$ in a good yield of $98 \%$ and with a diastereomeric ratio of 34:66 (Table 2, Entry 2). When $\mathrm{PPh}_{3}$ was used, a mixture of piperidines $6 \mathrm{c}$ and 7c was obtained in a 34:66 ratio with 99\% overall yield (Table 1, Entry 3). Decreasing the temperature to 0 ${ }^{\circ} \mathrm{C}$ allowed to obtain the final products $6 \mathrm{c}$ and $7 \mathrm{c}$ in lower yield (60\%) after $24 \mathrm{~h}$ but with significantly higher diastereoselectivity 23:77 (Table 2, Entry 4). On the other hand, increasing temperature to $60{ }^{\circ} \mathrm{C}$ gave a mixture of diastereoisomers in a 34:66 ratio (Table 2, Entry 5).

We also investigated the effect of the solvent on this cyclization reaction (Table 2, Entries 6-7). In $\mathrm{CH}_{2} \mathrm{Cl}_{2}$, products $6 \mathrm{c}$ and $7 \mathrm{c}$ was obtained as a 36:64 mixture of diastereoisomers in $99 \%$ overall yield. The use of $\mathrm{CH}_{3} \mathrm{CN}$ provided good yield: $98 \%$ and a low dr value of $45: 55$.

Table 2. Effect of the phosphine and solvent on the allylic amination of substrate $\mathbf{5} \mathbf{c}^{\mathrm{a}}$

\begin{tabular}{cccccc}
\hline Entry & Ligand & Solvent & $\mathrm{T}\left[{ }^{\circ} \mathrm{C}\right]$ & ${\text { Yield }(6+7)[\%]^{\mathrm{b}}}$ & $\mathrm{dr}^{\mathrm{c}}(6: 7)$ \\
\hline 1 & $\mathrm{dppb}$ & $\mathrm{THF}$ & 20 & 99 & $45: 55$ \\
2 & $\mathrm{dppe}$ & $\mathrm{THF}$ & 20 & 98 & $34: 66$ \\
3 & $\mathrm{PPh}_{3}$ & $\mathrm{THF}$ & 20 & 99 & $34: 66$ \\
4 & $\mathrm{PPh}_{3}$ & $\mathrm{THF}$ & 0 & 60 & $23: 77$ \\
5 & $\mathrm{PPh}_{3}$ & $\mathrm{THF}$ & 60 & 98 & $34: 66$ \\
6 & $\mathrm{PPh}_{3}$ & $\mathrm{CH}_{2} \mathrm{Cl}$ & 20 & 99 & $36: 64$ \\
7 & $\mathrm{PPh}_{3}$ & $\mathrm{CH}_{3} \mathrm{CN}$ & 20 & 98 & $45: 55$ \\
\hline
\end{tabular}

${ }^{a}$ Reaction conditions: $\left[\mathrm{Pd}_{2} \mathrm{dba}_{3}\right]:[\mathrm{dppb} / \mathrm{dppe}]:[5 \mathrm{c}]=1: 2.2: 20$ or $\left[\mathrm{Pd}_{2} \mathrm{dba}_{3}\right]:\left[\mathrm{PPh}_{3}\right]:[\mathbf{5 c}]=$ 1:4.4:20; 24 hours.

${ }^{\mathrm{b}}$ Isolated product. ${ }^{\mathrm{C}}$ Determined by ${ }^{1} \mathrm{H}$ NMR analysis.

The structures of the diastereomeric piperidines $6 \mathrm{c}$ and $7 \mathrm{c}$ were confirmed by IR, ${ }^{1} \mathrm{H}-\mathrm{NMR},{ }^{13} \mathrm{C}-\mathrm{NMR},{ }^{1} \mathrm{H}-{ }^{1} \mathrm{H}$ COSY and ${ }^{1} \mathrm{H}-{ }^{13} \mathrm{C}$ HMQC spectra. The most characteristic difference was observed for the vinyl substituent located on the 2-position of the piperidine ring. The diastereoisomer designated as $\mathbf{6 c}$, characterized by a lower polarity $\left(\mathrm{R}_{f}=0.83\right.$ hexane/ethyl acetate, $\left.3: 1\right)$ gave the signals from the protons of the vinyl moiety at lower values of ppm: $5.03\left(\mathrm{dd}, \mathrm{CH}=\mathrm{CH}_{2}\right), 5.15\left(\mathrm{dd}, \mathrm{CH}=\mathrm{CH}_{2}\right)$ and 5.39 (ddd, $\mathrm{CH}=\mathrm{CH}_{2}$ ). Diastereomer 7c (the more polar, $\mathrm{R}_{f}=0.70$ hexane/ethyl acetate, 3: 1) gave signals respectively at $5.18\left(\mathrm{dd}, \mathrm{CH}=\mathrm{CH}_{2}\right), 5.28(\mathrm{dd}$, $\mathrm{CH}=\mathrm{CH}_{2}$ ) and 5.89 (ddd, $\mathrm{CH}=\mathrm{CH}_{2}$ ).

The configuration of the isomeric products $6 c$ and $7 c$ was assigned based on the results obtained for $(S)-1-$ $((S)$-1-phenylethyl)-2-vinylpiperidine 7a and $(R)$-1-((R)-1-phenylethyl)-2-vinylpiperidine $6 \mathbf{b}$. We believe that the sense of asymmetric induction was the same and the major product of cyclization 5c corresponded to diastereomer 7c with an absolute $S$ configuration on the 2-position of the piperidine ring. It should be noted that higher values of chemical shifts of the vinylic protons of diastereoisomer $(2 S)-7 \mathrm{c}$ than $(2 R)-6 \mathrm{c}$ are in accord with literature data described by Fox and Gallagher for $N$-substituted-2-vinylpyrrolidine derivatives. ${ }^{50}$

Taking into account the results obtained for $\mathbf{5 c}$, the cyclizations of amino carbonates $\mathbf{5} \mathbf{d}$-j were performed in THF and $\mathrm{CH}_{2} \mathrm{Cl}_{2}$ in the presence of $\mathrm{PPh}_{3}$ as a ligand. Although the cyclization reaction with dppe as a ligand gave similar results, we decided to use $\mathrm{PPh}_{3}$ for further study for economic reasons.

The ring-closure of $\mathbf{5} \mathbf{d}$ occurred easily at room temperature in THF and provided 2-vinylpyrrolidines $(2 R)-6 \mathbf{d}$ and $(2 S)-7 \mathbf{d}$ as a $27: 73$ separable mixture of diastereoisomers in $99 \%$ yield (Table 3 , Entry 1 ). The same 
reaction in methylene chloride afforded a 33:67 mixture of diasteroisomers (Table 3, Entry 2). In these tests, the major isomer again corresponded to the more polar isomer $\mathbf{7 d}\left(R_{f 6 d}=0.81 ; R_{f 7 d}=0.65\right.$; hexane/ethyl acetate 3:1) and gave the signals of the vinylic protons at lower values of field $(4.99,5.12,5.35 \mathrm{ppm}$ for $(2 R)$ $\mathbf{6 d}$ and 5.15, 5.24, $5.86 \mathrm{ppm}$ for $\mathbf{7 d}$ ). The absolute configuration of $\mathbf{6 d}$ and $\mathbf{7 d}$ was assigned based on the results obtained with piperidine derivatives $6 \mathrm{a}-\mathrm{c}$ and $7 \mathrm{a}-\mathrm{c}$ and the literature data for $\mathrm{N}$-substituted-2vinylpyrrolidine derivatives. ${ }^{50}$

Table $3 \mathrm{Pd}^{0}$-Catalysed allylic amination of substrates $\mathbf{5 d - j ^ { a }}$

\begin{tabular}{cccccc}
\hline Entry & Carbonate & Solvent & $\mathrm{T}\left[{ }^{\circ} \mathrm{C}\right]$ & ${\text { Conv. }(\mathbf{6}+\mathbf{7})[\%]^{\mathrm{b}}}$ & $\mathrm{dr}^{\mathrm{b}}(\mathbf{6 : 7})$ \\
\hline 1 & $\mathbf{5 d}$ & $\mathrm{THF}$ & 20 & $99^{\mathrm{c}}$ & $27: 73$ \\
2 & $\mathbf{5 d}$ & $\mathrm{CH}_{2} \mathrm{Cl}_{2}$ & 20 & $99^{\mathrm{c}}$ & $33: 67$ \\
3 & $\mathbf{5 e}$ & $\mathrm{THF}$ & 20 & 0 & - \\
4 & $\mathbf{5 e}$ & $\mathrm{THF}$ & 60 & 100 & $45: 55$ \\
5 & $\mathbf{5 e}$ & $\mathrm{CH}_{2} \mathrm{Cl}_{2}$ & 35 & 100 & $48: 52$ \\
6 & $\mathbf{5 f}$ & $\mathrm{THF}$ & 20 & 100 & $42: 58$ \\
7 & $\mathbf{5 f}$ & $\mathrm{CH}_{2} \mathrm{Cl}{ }_{2}$ & 20 & 100 & $42: 58$ \\
8 & $\mathbf{5 g}$ & $\mathrm{THF}$ & 20 & 100 & $27: 73$ \\
9 & $\mathbf{5 g}$ & $\mathrm{CH}_{2} \mathrm{Cl}{ }_{2}$ & 20 & 100 & $34: 66$ \\
10 & $\mathbf{5 h}$ & $\mathrm{THF}$ & 20 & 0 & - \\
11 & $\mathbf{5 h}$ & $\mathrm{THF}$ & 60 & 100 & $40: 60$ \\
12 & $\mathbf{5 h}$ & $\mathrm{CH}_{2} \mathrm{Cl}{ }_{2}$ & 35 & 100 & $38: 62$ \\
13 & $\mathbf{5 i}$ & $\mathrm{THF}$ & 20 & 100 & $27: 73$ \\
14 & $\mathbf{5 j}$ & $\mathrm{THF}$ & 20 & 45 & $30: 70$ \\
15 & $\mathbf{5 j}$ & $\mathrm{THF}$ & 60 & 45 & $30: 70$ \\
\hline
\end{tabular}

${ }^{\mathrm{a}}$ Reaction conditions: $\left[\mathrm{Pd}_{2} \mathrm{dba}_{3}\right]:\left[\mathrm{PPh}_{3}\right]$ :[5] = 1:4.4:20; THF; 24 hours.

${ }^{\mathrm{b}}$ Determined by ${ }^{1} \mathrm{H}$ NMR analysis.

${ }^{\mathrm{c}}$ Isolated product.

The cyclization of alanine derivative $5 \mathbf{e}$ in THF at room temperature did not give the expected products $6 \mathbf{e}$ and $7 \mathrm{e}$ (Table 3, Entry 3). The reaction at $60^{\circ} \mathrm{C}$ afforded pyrrolidines $6 \mathrm{e}$ and $7 \mathrm{e}$ in $100 \%$ conversion with a $\mathrm{dr}$ of 45:55 after $20 \mathrm{~h}$ (Table 3, Entry 4). The reaction carried out in methylene chloride gave 6e and 7e with a very good yield but lower diastereoselectivity: $d r=48: 52$ (Table 3, Entry 5).

Amino carbonate $\mathbf{5 f}$ with a longer chain already at room temperature in THF gave the diastereomeric piperidines $6 f$ and $7 f$ in $100 \%$ conversion and $d r=42: 58$ Similar results were obtained for the reaction carried out in methylene chloride (Table 3, Entries 6-7). Unfortunately, an attempt to separate the resulting products was not successful but their structures were determined using spectroscopic methods. Cyclization of L-leucine derivative $\mathbf{5 g}$ at room temperature in THF gave an 27:73 inseparable mixture of stereoisomeric pyrrolidines $\mathbf{6 g}$ and $\mathbf{7 g}$ in $100 \%$ conversion (Table 3, Entry 8). Significantly lower level of diastereoselectivity was observed when the reaction was performed with the same amino carbonate $\mathbf{5 g}$ in methylene chloride - 34:66 dr (Table 3, Entry 9). In turn, the longer chain of the leucine derivative $\mathbf{5 h}$ did not undergo the cyclisation in THF at room temperature and in the NMR spectrum of the mixture of reactants no trace of the product was observed, even after prolonging the reaction time to 48 hours (Table 3, Entry 10). Diastereomeric piperidines $6 \mathrm{~h}$ and $7 \mathrm{~h}$ were obtained in $100 \%$ conversion and with a dr ratio of $40: 60$ after increase the temperature to $60{ }^{\circ} \mathrm{C}$ (Table 3 , 
Entry 11). The reaction performed in methylene chloride at an elevated temperature $\left(35^{\circ} \mathrm{C}\right)$ afforded the desired products in 100\% conversion and low dr value of 38:62 (Table 3, Entry 12). Finally, we tested the Lvaline derivatives $\mathbf{5 i}$ and $\mathbf{5 j}$ (Table 3, Entries 13-15). Ring-closure of $\mathbf{5 i}$ occurred readily in THF at room temperature and provided quantitatively 2-vinylpyrrolidines $\mathbf{6} \mathbf{i}$ and $\mathbf{7} \mathbf{i}$ as a 27:73 inseparable mixture of diastereoisomers. Carbonate $\mathbf{5} \mathbf{j}$ under these conditions appeared to be less reactive and gave piperidines $\mathbf{6 j}$ and $7 \mathbf{j}$ with a lower yield (45\% conversion) and selectivity (30:70 dr). Increasing the temperature to $60{ }^{\circ} \mathrm{C}$ did not result in decrease of reaction selectivity and yield. We have not performed the cyclization reactions of carbonates $\mathbf{5 i}$ and $\mathbf{5} \mathbf{j}$ in methylene chloride because the results obtained in earlier tests demonstrated a lower diastereoselectivity the reactions conducted in this solvent.

The stereoselectivities observed in the formation of piperidines $\mathbf{6}$ and $\mathbf{7}$ in the Pd-catalyzed cyclization of amino allylic carbonates $\mathbf{5} \mathbf{c}, \mathbf{f}, \mathbf{h}, \mathbf{j}$ could be explained on the base the Figure 3 .

We continue to maintain that the substituent on the nitrogen atom should be located in the pseudoequatorial orientation as mentioned previously. Additionally, a pseudo-axial orientation of the vinyl substituent on the $\mathrm{C}(2)$ carbon atom is necessary for the formation of the (2R)-6 isomer (Figure 3, Ilb). The size of the substituent plays decisive role in the formation such conformation and therefore the yields of the $(2 R)-6$ stereoisomer for substrates containing a small substituent, e.g. methyl, are higher [dr values $(2 R)-6 \mathbf{f}:(2 S)-7 f=$ 42:58] than for those containing more crowded substituents as benzyl or isopropyl (dr ratio above 33:67). In turn, the formation of a (2S)-7 stereoisomer (Figure 3, Ib) can be explained as before for phenylethanamine derivatives (Figure 1, la).

Similar considerations can be performed for 2-vinylpyrrolidines derivatives (Figure 3, Ic and IIc). The conformation Ic leads to the stereoisomer (2S)-7, whereas conformation Ilc leads to the stereoisomer (2R)-6.

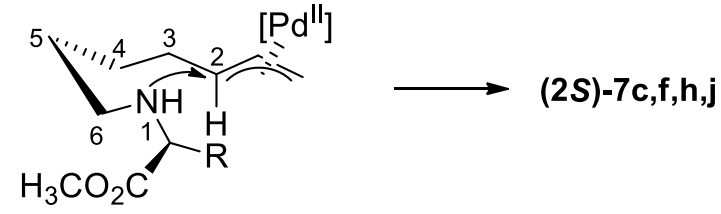

Ib: favored

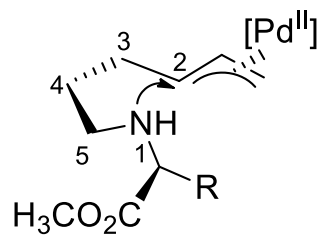

Ic: favored

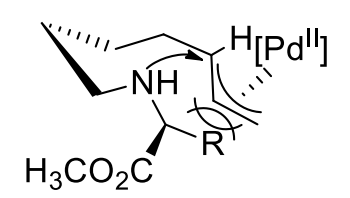

Ilb: disfavored
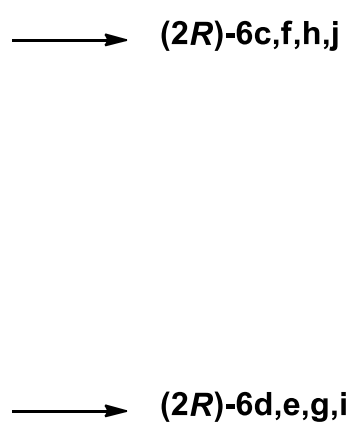

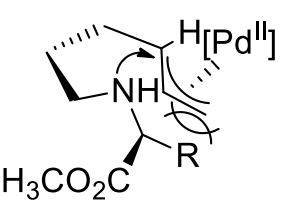

Ilc: disfavored

Figure 3. Models for $\mathrm{Pd}^{0}$-catalysed cyclization of $5 \mathrm{c}-\mathrm{j}$.

The reaction mechanism for this $\mathrm{Pd}(0)$-catalysed cyclization of amino carbonates containing chiral protecting group is shown in Scheme 3. Carbonate 5 reacted with $\mathrm{Pd}^{0}$ to give $\eta^{3}$-allylPd complex. Attack of the nitrogen nucleophile on the $\eta^{3}$-allyl intermediate followed by deprotonation gave the cyclic compounds 6 and 7. 


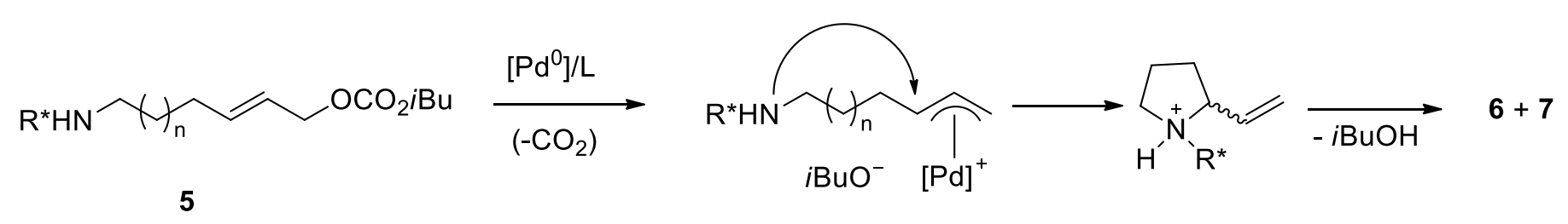

Scheme 3. Mechanism of the $\mathrm{Pd}^{0}$-catalysed cyclization.

\section{Conclusions}

In conclusion, we have developed a simple and efficient methodology for the synthesis of chiral nitrogencontaining heterocycles via $\mathrm{Pd}(0)$-catalysed cyclization of amino allylic carbonates containing chiral protecting group with known and specified absolute configuration. Using a methylbenzylamine-derived auxiliary, piperidine cyclization products can be accessed as single stereoisomers. Other auxiliaries derived from amino acids afforded moderate diastereomeric ratios of up to 23:77. Taking into account the obtained results and the literature data, we assume that in each of these cases the sense of asymmetric induction was the same and the major isomer coresponded to (2S)-7 rather than (2R)-6. Moreover, the N-chiral protecting group affect the stereochemical result of the reaction, and the steric hindrance of the $\mathrm{N}$-substituent determines the ratio of the formed diastereoisomers.

\section{Experimental Section}

General. All solvents and reagents were purchased from Sigma-Aldrich and were used as supplied, without additional purification. NMR spectra were recorded in $\mathrm{CDCl}_{3}$ on Bruker Avance III (600 MHz for ${ }^{1} \mathrm{H}$ NMR, 150 $\mathrm{MHz}$ for $\left.{ }^{13} \mathrm{C} \mathrm{NMR}\right)$, coupling constants are reported in $\mathrm{Hz}$. Chromatographic purification of compounds was achieved with $230-400$ mesh size silica gel. The progress of reactions was monitored by silica gel thin layer chromatography plates (Merck TLC Silicagel $60 \mathrm{~F}_{254}$ ).

\section{Typical procedure for the synthesis of aminocarbonates $5 \mathrm{a}, \mathrm{b}$}

1.5 M solution $i-\mathrm{Pr}_{2} \mathrm{NEt}$ in DMF (2.4 mL $i-\mathrm{Pr}_{2} \mathrm{NEt}$ in $\left.6.7 \mathrm{~mL} \mathrm{DMF}\right)$ and the corresponding amine: (S)-1phenylethanamine and $(R)$-1-phenylethanamine $(15.0 \mathrm{mmol})$ were added successively to a $0.8 \mathrm{M}$ solution of bromide $4 a-b(5.0 \mathrm{mmol})$ in DMF $(6.4 \mathrm{~mL})$. The reaction mixture was stirred at room temperature until the transformation of the bromide was complete (16-24 h), as indicated by thin layer chromatography. After being diluted with EtOAc $(30 \mathrm{~mL})$, the mixture was then washed with $\mathrm{H}_{2} \mathrm{O}(3 \times 20 \mathrm{~mL})$ and a saturated aqueous solution of $\mathrm{NaCl}(20 \mathrm{~mL})$. The organic layer was dried over $\mathrm{MgSO}_{4}$, filtered, and concentrated under reduced pressure. The crude product was purified by flash column chromatography on silica gel to give the allylic aminocarbonates $\mathbf{5 a , b}$.

(S,E)-Isobutyl \{7-[(1-phenylethyl)amino]hept-2-en-1-yl\} carbonate (5a). Colorless oil, $1.10 \mathrm{~g}, 66 \%$ yield; $\mathrm{R}_{f}$ (EtOAc/MeOH, $7:$ 1) 0.54; $[\alpha]_{\mathrm{D}}^{20}+27.4$ (c 0.5, $\mathrm{CHCl}_{3}$ ); $v_{\max }$ (liquid film) 3323, 3079, 3052, 2961, 2933, 2879, $2865,1740,1670,1513,1496,1473,1452,1248 \mathrm{~cm}^{-1} ; \delta_{\mathrm{H}}\left(600 \mathrm{MHz}, \mathrm{CDCl}_{3}\right) 0.94\left(\mathrm{~d}, 6 \mathrm{H}, J 6.7, \mathrm{CH}_{2} \mathrm{CH}\left(\mathrm{CH}_{3}\right)_{2}\right)$, 1.35-1.40 (m, 6H, CH3, H-5, NH), 1.44-1.51 (m, 2H, H-6), 1.93-1.98 (m, 1H, $\left.\mathrm{CH}_{2} \mathrm{CH}\left(\mathrm{CH}_{3}\right)_{2}\right), 2.02(\mathrm{q}, 2 \mathrm{H}, \mathrm{J} 7.3, \mathrm{H}-4)$, 2.39-2.43 (m, 1H, H-7), 2.48-2.52 (m, 1H, H-7), $3.76\left(\mathrm{q}, 1 \mathrm{H}, J 6.6, \mathrm{CHC}_{6} \mathrm{H}_{5}\right), 3.90\left(\mathrm{~d}, 2 \mathrm{H}, J 6.7, \mathrm{CH}_{2} \mathrm{CH}\left(\mathrm{CH}_{3}\right)_{2}\right), 4.54$ 
(d, 2H, J 6.5, H-1), 5.56 (dtt, $1 \mathrm{H}, \mathrm{J} 15.3,6.5,1.3, \mathrm{H}-2), 5.74-5.79(\mathrm{~m}, 1 \mathrm{H}, \mathrm{H}-3), 7.21-7.25\left(\mathrm{~m}, 1 \mathrm{H}, \mathrm{C}_{6} \mathrm{H}_{5}\right), 7.29-7.34$ $\left(\mathrm{m}, 4 \mathrm{H}, \mathrm{C}_{6} \mathrm{H}_{5}\right) ; \delta_{\mathrm{C}}\left(150 \mathrm{MHz}, \mathrm{CDCl}_{3}\right) \delta 18.9\left(\mathrm{CH}_{2} \mathrm{CH}\left(\mathrm{CH}_{3}\right)_{2}\right), 24.2\left(\mathrm{CH}_{3}\right), 26.5\left(\mathrm{CH}_{2} \mathrm{CH}\left(\mathrm{CH}_{3}\right)_{2}\right), 27.8(\mathrm{C}-4), 29.6(\mathrm{C}-5)$, 32.0 (C-6), 47.5 (C-7), $58.4\left(\mathrm{CHC}_{6} \mathrm{H}_{5}\right), 68.4(\mathrm{C}-1), 74.0\left(\mathrm{CH}_{2} \mathrm{CH}\left(\mathrm{CH}_{3}\right)_{2}\right), 123.6(\mathrm{C}-2), 126.6,127.0,128.4\left(\mathrm{C}_{6} \mathrm{H}_{5}\right)$, 136.9 (C-3), $145.5\left(\mathrm{C}_{\mathrm{q}}\right), 155.2$ (CO); MS-EI m/z: $334\left(\mathrm{MH}^{+}, 100\right)$; HRMS (EI): $\mathrm{M}^{+}$, found 333.2304. $\mathrm{C}_{20} \mathrm{H}_{31} \mathrm{NO}_{3}$ requires 333.2312.

$(R, E)$-Isobutyl \{7-[(1-phenylethyl)amino]hept-2-en-1-yl\} carbonate (5b). Colorless oil, $0.68 \mathrm{~g}, 41 \%$ yield; $\mathrm{R}_{f}$ (EtOAc/MeOH, $7: 1$ ) 0.53; $[\alpha]_{\mathrm{D}}^{20}-27.8$ (c 0.5, $\mathrm{CHCl}_{3}$ ); $v_{\max }$ (liquid film) 3326, 3080, 3058, 3036, 2958, 2930, 2879, 2868, 1742, 1672, 1515, 1496, 1470, 1454, $1249 \mathrm{~cm}^{-1} ; \delta_{\mathrm{H}}\left(600 \mathrm{MHz}_{\mathrm{CDCl}}\right) 0.95(\mathrm{~d}, 6 \mathrm{H}, \mathrm{J} 6.8$ $\left.\mathrm{CH}_{2} \mathrm{CH}\left(\mathrm{CH}_{3}\right)_{2}\right), 1.34\left(\mathrm{~d}, 3 \mathrm{H}, \mathrm{J} 6.6 \mathrm{CH}_{3}\right), 1.37-1.49(\mathrm{~m}, 5 \mathrm{H}, \mathrm{H}-5, \mathrm{H}-6, \mathrm{NH}), 1.93-2.00\left(\mathrm{~m}, 1 \mathrm{H}, \mathrm{CH}_{2} \mathrm{CH}\left(\mathrm{CH}_{3}\right)_{2}\right), 2.02(\mathrm{q}$, $2 \mathrm{H}, J$ 7.1, H-4), 2.39-2.43 (m, 1H, H-7), 2.47-2.51 (m, 1H, H-7), $3.75\left(\mathrm{q}, 1 \mathrm{H}, J\right.$ 6.6, $\left.\mathrm{CHC}_{6} \mathrm{H}_{5}\right), 3.91(\mathrm{~d}, 2 \mathrm{H}, J 6.7$, $\left.\mathrm{CH}_{2} \mathrm{CH}\left(\mathrm{CH}_{3}\right)_{2}\right), 4.54(\mathrm{~d}, 2 \mathrm{H}, J$ 6.6, H-1), 5.56 (dtt, $1 \mathrm{H}, J$ 15.4, 6.6, 1.4, H-2), 5.77 (dtt, 1H, J 15.4, 6.7, 1.02, H-3), 7.21-7.24 (m, $\left.1 \mathrm{H}, \mathrm{C}_{6} \mathrm{H}_{5}\right), 7.29-7.34\left(\mathrm{~m}, 4 \mathrm{H}, \mathrm{C}_{6} \mathrm{H}_{5}\right) ; \delta_{\mathrm{C}}\left(150 \mathrm{MHz}, \mathrm{CDCl}_{3}\right) \delta 18.8\left(\mathrm{CH}_{2} \mathrm{CH}\left(\mathrm{CH}_{3}\right)_{2}\right), 24.1\left(\mathrm{CH}_{3}-\mathrm{CH}\right), 26.4$ $\left(\mathrm{CH}_{2} \mathrm{CH}\left(\mathrm{CH}_{3}\right)_{2}\right), 27.7$ (C-4), 29.5 (C-5), 31.9 (C-6), 47.4 (C-7), $58.3\left(\mathrm{CHC}_{6} \mathrm{H}_{5}\right), 68.3(\mathrm{C}-1), 73.9\left(\mathrm{CH}_{2} \mathrm{CH}\left(\mathrm{CH}_{3}\right)_{2}\right), 123.5$ (C-2), 126.5, 126.8, $128.3\left(\mathrm{C}_{6} \mathrm{H}_{5}\right), 136.8$ (C-3), 155.2 (CO); MS-El m/z: $334\left(\mathrm{MH}^{+}, 100\right)$; found: C, 71.61; H, 9.18; $\mathrm{N}, 4.38 . \mathrm{C}_{20} \mathrm{H}_{31} \mathrm{NO}_{3}$ requires $\mathrm{C}, 72.04 ; \mathrm{H}, 9.37 ; \mathrm{N}, 4.20 \%$.

\section{Typical procedure for the synthesis of aminocarbonate $5 c-j$}

A solution of appropriate bromide $4 \mathrm{a}-\mathrm{b}$ (0.5 g, 1 equiv.), $\mathrm{K}_{2} \mathrm{CO}_{3}$ (2 equiv.), appropriate amino acid hydrochloride (3 equiv.) in $\mathrm{CH}_{3} \mathrm{CN}\left(8 \mathrm{~mL}\right.$ ) was stirred at $40{ }^{\circ} \mathrm{C}$ for $4 \mathrm{~d}$. Then the reaction mixture was cooled, diluted with water $(20 \mathrm{~mL})$ and extracted with ethyl acetate $(3 \times 20 \mathrm{~mL})$. The combined organic phases were washed with brine, dried over $\mathrm{Na}_{2} \mathrm{SO}_{4}$ and evaporated under reduced pressure to give clear liquid. The crude product was purified by flash column chromatography on silica gel to give allylic aminocarbonate $\mathbf{5 c - j}$.

(S,E)-Methyl 2-(\{7-[(isobutoxycarbonyl)oxy\}]hept-5-en-1-yl\}amino)-3-phenylpropanoate (5c). Colorless oil, 0.29 g, 43\% yield; $\mathrm{R}_{f}$ (hexane/EtOAc, $3: 1$ ) 0.53; $[\alpha]_{\mathrm{D}}^{20}+13.7$ (c 0.5, $\mathrm{CHCl}_{3}$ ); $v_{\max }$ (liquid film) 3329, 3062, 3029, 2930, 2856, 1740, 1674, 1605, 1496, 1456, $1251 \mathrm{~cm}^{-1} ; \delta_{\mathrm{H}}\left(600 \mathrm{MHz}, \mathrm{CDCl}_{3}\right) 0.94$ (d, 6H, J 6.7, $\left.\mathrm{CH}_{2} \mathrm{CH}\left(\mathrm{CH}_{3}\right)_{2}\right)$, 1.33-1.39 (m, 2H, H-5), 1.40-1.48 (m, 2H, H-6), $\left.1.53(\mathrm{~s}, 1 \mathrm{H}, \mathrm{NH}), 1.93-2.00\left(\mathrm{~m}, 1 \mathrm{H}, \mathrm{CH}_{2} \mathrm{CH}_{\left(\mathrm{CH}_{3}\right)}\right)_{2}\right), 2.03(\mathrm{q}, 2 \mathrm{H}, J$ 7.1, H-4), 2.41-2.48 (m, 1H, H-7), 2.54-2.61 (m, 1H, H-7), $2.95\left(\mathrm{~d}, 2 \mathrm{H}, J\right.$ 7.0, $\left.\mathrm{CH}_{2} \mathrm{C}_{6} \mathrm{H}_{5}\right), 3.50(\mathrm{t}, 1 \mathrm{H}, J \mathrm{~J} .2, \mathrm{NHCH})$, $3.64\left(\mathrm{~s}, 3 \mathrm{H}, \mathrm{COOCH}_{3}\right), 3.92\left(\mathrm{~d}, 2 \mathrm{H}, J\right.$ 6.7, $\left.\mathrm{CH}_{2} \mathrm{CH}\left(\mathrm{CH}_{3}\right)_{2}\right), 4.56(\mathrm{~d}, 2 \mathrm{H}, J 6.7, \mathrm{H}-1), 5.58(\mathrm{dt}, 1 \mathrm{H}, J$ 15.4, 6.3, H-3), $5.77(\mathrm{dt}, 1 \mathrm{H}, J 15.4,6.7, \mathrm{H}-2), 7.10-7.33\left(\mathrm{~m}, 5 \mathrm{H}, \mathrm{C}_{6} \mathrm{H}_{5}\right) ; \delta_{\mathrm{C}}\left(150 \mathrm{MHz}, \mathrm{CDCl}_{3}\right) \delta 19.0\left(\mathrm{CH}_{2} \mathrm{CH}\left(\mathrm{CH}_{3}\right)_{2}\right), 26.4(\mathrm{C}-5)$, 27.9 (C-6), $29.6\left(\mathrm{CH}_{2} \mathrm{CH}\left(\mathrm{CH}_{3}\right)_{2}\right), 32.0$ (C-4), $39.8\left(\mathrm{CH}_{2} \mathrm{C}_{6} \mathrm{H}_{5}\right), 48.0(\mathrm{C}-7), 51.6\left(\mathrm{COOCH}_{3}\right), 63.2(\mathrm{NHCH}), 68.5(\mathrm{C}-1)$, $74.1\left(\mathrm{CH}_{2} \mathrm{CH}\left(\mathrm{CH}_{3}\right)_{2}\right), 123.7$ (C-2), 126.8, 128.5, 129.2, $136.9\left(\mathrm{C}_{6} \mathrm{H}_{5}\right), 137.5$ (C-3), 155.3 (CO), 175.2 (CO); found: C, $67.51 ; \mathrm{H}, 8.76 ; \mathrm{N}, 3.59 . \mathrm{C}_{22} \mathrm{H}_{33} \mathrm{NO}_{5}$ requires $\mathrm{C}, 67.49 ; \mathrm{H}, 8.50 ; \mathrm{N}, 3.58 \%$.

(S,E)-Methyl 2-(\{6-[(isobutoxycarbonyl)oxy]hex-4-en-1-yl\}amino)-3-phenylpropanoate (5d). Colorless oil, $0.32 \mathrm{~g}, 48 \%$ yield; $\mathrm{R}_{f}$ (hexane/EtOAc, $\left.3: 1\right) 0.51 ;[\alpha]_{\mathrm{D}}^{20}-6.4$ (c 0.5, $\mathrm{CHCl}_{3}$ ); $v_{\max }$ (liquid film) 3327, 3029, 2955, $2875,1740,1670,1605,1497,1456,1254 \mathrm{~cm}^{-1} ; \delta_{\mathrm{H}}\left(600 \mathrm{MHz}, \mathrm{CDCl}_{3}\right) 0.87\left(\mathrm{~d}, 6 \mathrm{H}, J 6.7, \mathrm{CH}_{2} \mathrm{CH}\left(\mathrm{CH}_{3}\right)_{2}\right), 1.38-1.50$ (m, 2H, H-5), $1.59(\mathrm{~s}, 1 \mathrm{H}, \mathrm{NH}), 1.85-1.92\left(\mathrm{~m}, 1 \mathrm{H}, \mathrm{CH}_{2} \mathrm{CH}\left(\mathrm{CH}_{3}\right)_{2}\right), 1.96(\mathrm{q}, 2 \mathrm{H}, J$ 6.8, H-4), 2.34-2.41 (m, 1H, H-6), 2.47-2.55 (m, $1 \mathrm{H}, \mathrm{H}-6), 2.85\left(\mathrm{~d}, 2 \mathrm{H}, J\right.$ 6.9, $\left.\mathrm{CH}_{2} \mathrm{C}_{6} \mathrm{H}_{5}\right), 3.41\left(\mathrm{t}, 1 \mathrm{H}, J\right.$ 6.9, NHCH), $3.55\left(\mathrm{~s}, 3 \mathrm{H}, \mathrm{COOCH}_{3}\right), 3.83(\mathrm{~d}, 2 \mathrm{H}$, J 6.6, $\left.\mathrm{CH}_{2} \mathrm{CH}\left(\mathrm{CH}_{3}\right)_{2}\right), 4.46(\mathrm{~d}, 2 \mathrm{H}, J$ 6.6, $\mathrm{H}-1), 5.48(\mathrm{dt}, 1 \mathrm{H}, J 15.5,6.5, \mathrm{H}-3), 5.68(\mathrm{dt}, 1 \mathrm{H}, J 15.5,6.6, \mathrm{H}-2), 7.00-$ $7.25\left(\mathrm{~m}, 5 \mathrm{H}, \mathrm{C}_{6} \mathrm{H}_{5}\right) ; \delta_{\mathrm{c}}\left(150 \mathrm{MHz}, \mathrm{CDCl}_{3}\right) \delta 19.1\left(\mathrm{CH}_{2} \mathrm{CH}\left(\mathrm{CH}_{3}\right)_{2}\right), 26.5(\mathrm{C}-4), 27.9(\mathrm{C}-5), 29.6\left(\mathrm{CH}_{2} \mathrm{CH}\left(\mathrm{CH}_{3}\right)_{2}\right), 39.9$ $\left(\mathrm{CH}_{2} \mathrm{C}_{5} \mathrm{H}_{4}\right), 48.1(\mathrm{C}-6), 51.7\left(\mathrm{COOCH}_{3}\right), 63.3(\mathrm{NHCH}), 68.5(\mathrm{C}-1), 74.2\left(\mathrm{CH}_{2} \mathrm{CH}\left(\mathrm{CH}_{3}\right)_{2}\right), 123.8(\mathrm{C}-2), 126.8,128.6$, 129.3, $137.5\left(\mathrm{C}_{6} \mathrm{H}_{5}\right), 136.9$ (C-3), 155.4 (CO), 175.2 (CO); found: $\mathrm{C}, 67.09 ; \mathrm{H}, 8.52 ; \mathrm{N}, 3.52 . \mathrm{C}_{21} \mathrm{H}_{31} \mathrm{NO}_{5}$ requires $\mathrm{C}$, $66.82 ; \mathrm{H}, 8.28 ; \mathrm{N}, 3.71 \%$.

(S,E)-Methyl 2-(\{6-[(isobutoxycarbonyl)oxy]hex-4-en-1-yl\}amino)propanoate (5e). Colorless oil, $0.18 \mathrm{~g}, 34 \%$ yield; $\mathrm{R}_{f}$ (hexane/EtOAc, $3: 1$ ) 0.44; $[\alpha]_{\mathrm{D}}^{20}-12.5$ (c 1, $\mathrm{CHCl}_{3}$ ); $v_{\max }$ (liquid film) 3329, 2960, 2865, 1747, 1674, $1254 \mathrm{~cm}^{-1} ; \delta_{\mathrm{H}}\left(600 \mathrm{MHz}, \mathrm{CDCl}_{3}\right) 0.88\left(\mathrm{~d}, 6 \mathrm{H}, J\right.$ 6.7, $\left.\mathrm{CH}_{2} \mathrm{CH}\left(\mathrm{CH}_{3}\right)_{2}\right), 1.23\left(\mathrm{~d}, 3 \mathrm{H}, J\right.$ 7.0, $\left.\mathrm{CHCH}_{3}\right), 1.48-1.54(\mathrm{~m}, 2 \mathrm{H}, \mathrm{H}-$ 
5), $1.56(\mathrm{~s}, 1 \mathrm{H}, \mathrm{NH}), 1.87-1.93\left(\mathrm{~m}, 1 \mathrm{H}, \mathrm{CH}_{2} \mathrm{CH}\left(\mathrm{CH}_{3}\right)_{2}\right), 2.05$ (q, 2H, J 7.0, H-4), 2.40-2.44 (m, 1H, H-6), $2.50-2.55$ (m, $1 \mathrm{H}, \mathrm{H}-6), 3.25-3.29\left(\mathrm{~m}, 1 \mathrm{H}, \mathrm{NHCHCH}_{3}\right), 3.65\left(\mathrm{~s}, 3 \mathrm{H}, \mathrm{COOCH}_{3}\right), 3.85\left(\mathrm{~d}, 2 \mathrm{H}, J 6.7, \mathrm{CH}_{2} \mathrm{CH}\left(\mathrm{CH}_{3}\right)_{2}\right), 4.49(\mathrm{~d}, 2 \mathrm{H}, J$ 6.4, H-1), 5.51-5.57 (m, $1 \mathrm{H}, \mathrm{H}-3), 5.71-5.77(\mathrm{~m}, 1 \mathrm{H}, \mathrm{H}-2) ; \delta_{\mathrm{c}}\left(150 \mathrm{MHz}, \mathrm{CDCl}_{3}\right) \delta 19.0\left(\mathrm{CH}_{2} \mathrm{CH}\left(\mathrm{CH}_{3}\right)_{2}\right), 19.1$ $\left(\mathrm{CH}_{2} \mathrm{CH}\left(\mathrm{CH}_{3}\right)_{2}\right), 27.9\left(\mathrm{CH}_{2} \mathrm{CH}\left(\mathrm{CH}_{3}\right)_{2}\right), 29.4(\mathrm{C}-4), 30.0$ (C-5), $47.5(\mathrm{C}-6), 51.8\left(\mathrm{COOCH}_{3}\right), 56.7\left(\mathrm{NHCHCH}_{3}\right), 68.4(\mathrm{C}-$ 1), $74.0\left(\mathrm{CH}_{2} \mathrm{CH}\left(\mathrm{CH}_{3}\right)_{2}\right), 124.0$ (C-2), 136.5 (C-3), 155.3 (CO), 176.3 (CO); found: C, 59.62; H, 9.16; N, 4.68. $\mathrm{C}_{15} \mathrm{H}_{27} \mathrm{NO}_{5}$ requires $\mathrm{C}, 59.78 ; \mathrm{H}, 9.03 ; \mathrm{N}, 4.65 \%$.

(S,E)-Methyl 2-(\{7-[(isobutoxycarbonyl)oxy]hept-5-en-1-yl\}amino)propanoate (5f). Colorless oil, $0.34 \mathrm{~g}, 63 \%$ yield; $\mathrm{R}_{f}$ (hexane/EtOAc, $3: 1$ ) 0.34; $[\alpha]_{\mathrm{D}}^{20}-14.0$ (c 1, $\mathrm{CHCl}_{3}$ ); $v_{\max }$ (liquid film) 3329, 2965, 2875, 2791, 1747, $1670,1261 \mathrm{~cm}^{-1} ; \delta_{\mathrm{H}}\left(600 \mathrm{MHz}, \mathrm{CDCl}_{3}\right) 0.90$ (d, 6H, J 6.7, $\left.\mathrm{CH}_{2} \mathrm{CH}\left(\mathrm{CH}_{3}\right)_{2}\right), 1.24$ (d, 3H, J 7.0, $\left.\mathrm{CHCH}_{3}\right), 1.33-1.47(\mathrm{~m}$, $4 \mathrm{H}, \mathrm{H}-5, \mathrm{H}-6), 1.58(\mathrm{~s}, 1 \mathrm{H}, \mathrm{NH}), 1.88-1.95\left(\mathrm{~m}, 1 \mathrm{H}, \mathrm{CH}_{2} \mathrm{CH}\left(\mathrm{CH}_{3}\right)_{2}\right), 2.02(\mathrm{q}, 2 \mathrm{H}, J$ 7.0, H-4), 2.40-2.42 (m, 1H, H-7), 2.49-2.54 (m, 1H, H-7), 3.26-3.31 (m, 1H, $\left.\mathrm{NHCHCH}_{3}\right), 3.67\left(\mathrm{~s}, 3 \mathrm{H}, \mathrm{COOCH}_{3}\right), 3.86\left(\mathrm{~d}, 2 \mathrm{H}, J 6.7, \mathrm{CH}_{2} \mathrm{CH}\left(\mathrm{CH}_{3}\right)_{2}\right)$, $4.50\left(\mathrm{~d}, 2 \mathrm{H}, J\right.$ 6.4, H-1), 5.52-5.57 (m, 1H, H-3), 5.72-5.77 (m, 1H, H-2); $\delta_{\mathrm{c}}\left(150 \mathrm{MHz}^{\mathrm{C}} \mathrm{CDCl}\right) \delta 19.0$ $\left(\mathrm{CH}_{2} \mathrm{CH}\left(\mathrm{CH}_{3}\right)_{2}\right), 19.2\left(\mathrm{CH}_{2} \mathrm{CH}\left(\mathrm{CH}_{3}\right)_{2}\right), 26.6\left(\mathrm{CH}_{2} \mathrm{CH}\left(\mathrm{CH}_{3}\right)_{2}\right), 27.9$ (C-5), 29.8 (C-4), 32.1 (C-6), 47.9 (C-7), 51.8 $\left(\mathrm{COOCH}_{3}\right), 56.8\left(\mathrm{NHCHCH}_{3}\right), 68.5(\mathrm{C}-1), 74.2\left(\mathrm{CH}_{2} \mathrm{CH}\left(\mathrm{CH}_{3}\right)_{2}\right), 123.8$ (C-2), 136.9 (C-3), 155.4 (CO), 176.4 (CO); found: $\mathrm{C}, 60.98 ; \mathrm{H}, 9.21 ; \mathrm{N}, 4.45$. $\mathrm{C}_{16} \mathrm{H}_{29} \mathrm{NO}_{5}$ requires $\mathrm{C}, 60.93 ; \mathrm{H}, 9.27 ; \mathrm{N}, 4.44 \%$.

(S,E)-Methyl 2-(\{6-[(isobutoxycarbonyl)oxy]hex-4-en-1-yl\}amino)-4-methylpentanoate (5g). Colorless oil, $0.23 \mathrm{~g}, 38 \%$ yield; $\mathrm{R}_{f}$ (hexane/EtOAc, $3: 1$ ) 0.49; $[\alpha]_{\mathrm{D}}^{20}-6.6$ (c 0.5, $\mathrm{CHCl}_{3}$ ); $v_{\max }$ (liquid film) 3329, 2957, 2872, 1740, 1670, $1252 \mathrm{~cm}^{-1} ; \delta_{\mathrm{H}}\left(600 \mathrm{MHz}, \mathrm{CDCl}_{3}\right) 0.86\left(\mathrm{~d}, 3 \mathrm{H}, J 6.6, \mathrm{CHCH}_{2} \mathrm{CH}\left(\mathrm{CH}_{3}\right)_{2}\right), 0.88$ (d, 3H, J 6.6, $\left.\mathrm{CHCH}_{2} \mathrm{CH}\left(\mathrm{CH}_{3}\right)_{2}\right), 0.91\left(\mathrm{~d}, 6 \mathrm{H}, J 6.7, \mathrm{CH}_{2} \mathrm{CH}\left(\mathrm{CH}_{3}\right)_{2}\right), 1.39-1.43(\mathrm{~m}, 2 \mathrm{H}, \mathrm{H}-5), 1.47-1.55\left(\mathrm{~m}, 2 \mathrm{H}, \mathrm{CHCH} 2 \mathrm{CH}\left(\mathrm{CH}_{3}\right)_{2}\right)$, 1.64-1.70 (m, 2H, NH, $\left.\mathrm{CHCH}_{2} \mathrm{CH}\left(\mathrm{CH}_{3}\right)_{2}\right), 1.90-1.96\left(\mathrm{~m}, 1 \mathrm{H}, \mathrm{CH}_{2} \mathrm{CH}\left(\mathrm{CH}_{3}\right)_{2}\right), 2.06$ (q, 2H, J 7.2, H-4), 2.37-2.41 (m, $1 \mathrm{H}, \mathrm{H}-6), 2.52-2.56(\mathrm{~m}, 1 \mathrm{H}, \mathrm{H}-6), 3.21(\mathrm{t}, 1 \mathrm{H}, J \mathrm{~J} .3, \mathrm{CHNH}), 3.67\left(\mathrm{~s}, 3 \mathrm{H}, \mathrm{COOCH}_{3}\right), 3.87(\mathrm{~d}, 2 \mathrm{H}, J 6.6$, $\left.\mathrm{CH}_{2} \mathrm{CH}\left(\mathrm{CH}_{3}\right)_{2}\right), 4.52\left(\mathrm{~d}, 2 \mathrm{H}, J\right.$ 6.4, H-1), $5.56\left(\mathrm{dt}, 1 \mathrm{H}, J\right.$ 15.4, 6.5, H-3), $5.76\left(\mathrm{dt}, 1 \mathrm{H}, J\right.$ 15.4, 6.7, H-2); $\delta_{\mathrm{C}}(150 \mathrm{MHz}$, $\left.\mathrm{CDCl}_{3}\right) \delta 19.0$ and $19.0\left(\mathrm{CH}_{2} \mathrm{CH}\left(\mathrm{CH}_{3}\right)_{2}\right), 22.5$ and $22.8\left(\mathrm{CHCH}_{2} \mathrm{CH}\left(\mathrm{CH}_{3}\right)_{2}\right), 25.1\left(\mathrm{CHCH}_{2} \mathrm{CH}\left(\mathrm{CH}_{3}\right)_{2}\right), 27.9$ $\left(\mathrm{CH}_{2} \mathrm{CH}\left(\mathrm{CH}_{3}\right)_{2}\right), 29.4$ (C-5), 30.0 (C-4), $43.0\left(\mathrm{CHCH}_{2} \mathrm{CH}\left(\mathrm{CH}_{3}\right)_{2}\right), 47.7$ (C-6), $51.7\left(\mathrm{COOCH}_{3}\right), 60.2(\mathrm{NHCH}), 68.5(\mathrm{C}-1)$, $74.2\left(\mathrm{CH}_{2} \mathrm{CH}\left(\mathrm{CH}_{3}\right)_{2}\right), 123.9$ (C-2), 136.6 (C-3), 155.4 (CO), 176.7 (CO); found: C, 63.11; H, 9.76; N, 3.89. $\mathrm{C}_{18} \mathrm{H}_{33} \mathrm{NO}_{5}$ requires $\mathrm{C}, 62.95 ; \mathrm{H}, 9.68 ; \mathrm{N}, 4.08 \%$.

(S,E)-Methyl 2-(\{7-[(isobutoxycarbonyl)oxy]hept-5-en-1-yl\}amino)-4-methylpentanoate (5h). Colorless oil, $0.30 \mathrm{~g}, 50 \%$ yield; $\mathrm{R}_{f}$ (hexane/EtOAc, $\left.3: 1\right) 0.53 ;[\alpha]_{\mathrm{D}}^{20}-4.0\left(c \mathrm{cos}, \mathrm{CHCl}_{3}\right.$ ); $v_{\max }$ (liquid film) 3330, 2956, 2931, 2872, 1740, 1674, $1252 \mathrm{~cm}^{-1} ; \delta_{\mathrm{H}}\left(600 \mathrm{MHz}, \mathrm{CDCl}_{3}\right) 0.86\left(\mathrm{~d}, 3 \mathrm{H}, J 6.6, \mathrm{CHCH}_{2} \mathrm{CH}\left(\mathrm{CH}_{3}\right)_{2}\right), 0.89(\mathrm{~d}, 3 \mathrm{H}, J 6.6$, $\left.\mathrm{CHCH}_{2} \mathrm{CH}\left(\mathrm{CH}_{3}\right)_{2}\right), 0.92$ (d, 6H, J 6.7, $\left.\mathrm{CH}_{2} \mathrm{CH}\left(\mathrm{CH}_{3}\right)_{2}\right), 1.36-1.45\left(\mathrm{~m}, 6 \mathrm{H}, \mathrm{CHCH}_{2} \mathrm{CH}\left(\mathrm{CH}_{3}\right) 2, \mathrm{H}-5, \mathrm{H}-6\right), 1.63-1.70(\mathrm{~m}$, $\left.2 \mathrm{H}, \mathrm{NH}, \mathrm{CHCH}_{2} \mathrm{CH}\left(\mathrm{CH}_{3}\right)_{2}\right), 1.90-1.96\left(\mathrm{~m}, 1 \mathrm{H}, \mathrm{CH}_{2} \mathrm{CH}\left(\mathrm{CH}_{3}\right)_{2}\right), 2.03$ (q, 2H, J 7.2, H-4), 2.37-2.42 (m, 1H, H-7), 2.50-

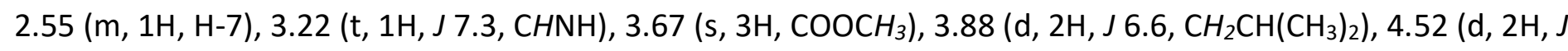
6.5, $\mathrm{H}-1)$, 5.51-5.57 (m, $1 \mathrm{H}, \mathrm{H}-3), 5.72-5.79(\mathrm{~m}, 1 \mathrm{H}, \mathrm{H}-2) ; \delta_{\mathrm{c}}\left(150 \mathrm{MHz}, \mathrm{CDCl}_{3}\right) \delta 19.1$ and $19.1\left(\mathrm{CH}_{2} \mathrm{CH}\left(\mathrm{CH}_{3}\right)_{2}\right)$, 22.5 and $22.8\left(\mathrm{CHCH}_{2} \mathrm{CH}\left(\mathrm{CH}_{3}\right)_{2}\right), 25.2\left(\mathrm{CHCH}_{2} \mathrm{CH}\left(\mathrm{CH}_{3}\right)_{2}\right), 26.6\left(\mathrm{CH}_{2} \mathrm{CH}\left(\mathrm{CH}_{3}\right)_{2}\right), 28.0$ (C-5), 29.9 (C-6), 32.2 (C-4),

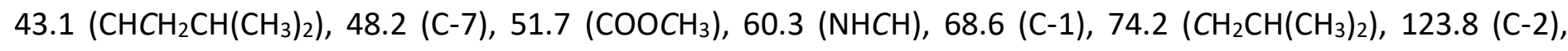
137.1 (C-3), 155.5 (CO), 176.8 (CO); found: $\mathrm{C}, 64.02 ; \mathrm{H}, 10.03 ; \mathrm{N}, 3.98 . \mathrm{C}_{19} \mathrm{H}_{35} \mathrm{NO}_{5}$ requires $\mathrm{C}, 63.84 ; \mathrm{H}, 9.87 ; \mathrm{N}$, $3.92 \%$.

(S,E)-Methyl 2-(\{6-[(isobutoxycarbonyl)oxy]hex-4-en-1-yl\}amino)-3-methylbutanoate (5i). Colorless oil, 0.18 $\mathrm{g}, 31 \%$ yield; $\mathrm{R}_{f}$ (hexane/EtOAc, $3: 1$ ) 0.42; $[\alpha]_{\mathrm{D}}^{20}-8.0$ (c 0.5, $\mathrm{CHCl}_{3}$ ); $v_{\max }$ (liquid film) 3329, 2932, 2856, 1741, 1670, $1250 \mathrm{~cm}^{-1} ; \delta_{\mathrm{H}}\left(600 \mathrm{MHz}, \mathrm{CDCl}_{3}\right) 0.92$ (d, 3H, J 6.8, $\left.\mathrm{CHCH}\left(\mathrm{CH}_{3}\right)_{2}\right), 0.93\left(\mathrm{~d}, 3 \mathrm{H}, \mathrm{J} 6.8, \mathrm{CHCH}\left(\mathrm{CH}_{3}\right)_{2}\right), 0.94(\mathrm{~d}$, $6 \mathrm{H}, J$ 6.8, $\left.\mathrm{CH}_{2} \mathrm{CH}\left(\mathrm{CH}_{3}\right)_{2}\right), 1.44(\mathrm{~s}, 1 \mathrm{H}, \mathrm{NH}), 1.50-1.60(\mathrm{~m}, 2 \mathrm{H}, \mathrm{H}-5), 1.84-1.91\left(\mathrm{~m}, 1 \mathrm{H}, \mathrm{CHCH}\left(\mathrm{CH}_{3}\right)_{2}\right), 1.93-2.00(\mathrm{~m}$, $\left.1 \mathrm{H}, \mathrm{CH}_{2} \mathrm{CH}\left(\mathrm{CH}_{3}\right)_{2}\right), 2.11$ (q, 2H, J 7.3, H-4), 2.39 (dt, 1H, J 11.2, 7.0, H-6), 2.659 (dt, 1H, J 11.2, 6.7, H-6), 2.94 (d, $1 \mathrm{H}, J$ 6.1, $\left.\mathrm{CHCH}\left(\mathrm{CH}_{3}\right)_{2}\right), 3.71\left(\mathrm{~s}, 3 \mathrm{H}, \mathrm{COOCH}_{3}\right), 3.91\left(\mathrm{~d}, 2 \mathrm{H}, J 6.7, \mathrm{CH}_{2} \mathrm{CH}\left(\mathrm{CH}_{3}\right)_{2}\right), 4.55(\mathrm{~d}, 2 \mathrm{H}, J 6.5, \mathrm{H}-1), 5.60$ (dt, $1 \mathrm{H}, J$ 15.2, 6.5, H-3), $5.80(\mathrm{dt}, 1 \mathrm{H}, J 15.2,6.7, \mathrm{H}-2) ; \delta_{c}\left(150 \mathrm{MHz}, \mathrm{CDCl}_{3}\right) \delta 18.9,19.0,19.0,19.3\left(\mathrm{CH}_{3}\right), 27.9$ 
$\left(\mathrm{CH}_{2} \mathrm{CH}\left(\mathrm{CH}_{3}\right)_{2}\right), 29.4$ (C-5), 30.0 (C-4), $31.8\left(\mathrm{CHCH}\left(\mathrm{CH}_{3}\right)_{2}\right), 48.1(\mathrm{C}-6), 51.4\left(\mathrm{COOCH}_{3}\right), 67.6(\mathrm{NHCH}), 68.5(\mathrm{C}-1)$, $74.1\left(\mathrm{CH}_{2} \mathrm{CH}\left(\mathrm{CH}_{3}\right)_{2}\right), 123.8$ (C-2), 136.8 (C-3), 155.4 (CO), 176.0 (CO); found: C, 62.12; $\mathrm{H}, 9.61 ; \mathrm{N}, 4.16$. $\mathrm{C}_{17} \mathrm{H}_{31} \mathrm{NO}_{5}$ requires $\mathrm{C}, 61.98 ; \mathrm{H}, 9.48 ; \mathrm{N}, 4.25 \%$.

(S,E)-Methyl 2-(\{7-[(isobutoxycarbonyl)oxy]hept-5-en-1-yl\}amino)-3-methylbutanoate (5j). Colorless oil, 0.12 g, 21\% yield; $\mathrm{R}_{f}$ (hexane/EtOAc, $3: 1$ ) 0.41; $[\alpha]_{\mathrm{D}}^{20}-0.18$ (c 1, $\mathrm{CHCl}_{3}$ ); $v_{\max }$ (liquid film) 3328, 2931, 2856, 1741, $1673,1250 \mathrm{~cm}^{-1} ; \delta_{\mathrm{H}}\left(600 \mathrm{MHz}, \mathrm{CDCl}_{3}\right) 0.92\left(\mathrm{~d}, 3 \mathrm{H}, J\right.$ 6.7, $\left.\mathrm{CHCH}\left(\mathrm{CH}_{3}\right)_{2}\right), 0.95\left(\mathrm{~d}, 3 \mathrm{H}, J\right.$ 6.7, $\left.\mathrm{CHCH}\left(\mathrm{CH}_{3}\right)_{2}\right), 0.97(\mathrm{~d}$, $6 \mathrm{H}, J$ 6.7, $\left.\mathrm{CH}_{2} \mathrm{CH}\left(\mathrm{CH}_{3}\right)_{2}\right), 1.38-1.45(\mathrm{~m}, 4 \mathrm{H}, \mathrm{H}-5, \mathrm{H}-6), 1.58(\mathrm{~s}, 1 \mathrm{H}, \mathrm{NH}), 1.83-1.92\left(\mathrm{~m}, 1 \mathrm{H}, \mathrm{CHCH}\left(\mathrm{CH}_{3}\right)_{2}\right), 1.93-2.01$ $\left(\mathrm{m}, 1 \mathrm{H}, \mathrm{CH}_{2} \mathrm{CH}\left(\mathrm{CH}_{3}\right)_{2}\right), 2.07$ (q, 2H, J 6.8, H-4), 2.40 (dt, 1H, J 11.2, 7.7, H-7), 2.57 (dt, $1 \mathrm{H}, J$ 11.2, 6.2, H-7), 2.97 (d, $1 \mathrm{H}, J$ 6.2, $\left.\mathrm{CHCH}\left(\mathrm{CH}_{3}\right)_{2}\right), 3.72\left(\mathrm{~s}, 3 \mathrm{H}, \mathrm{COOCH}_{3}\right), 3.91$ (d, 2H, J 6.7, $\left.\mathrm{CH}_{2} \mathrm{CH}\left(\mathrm{CH}_{3}\right)_{2}\right), 4.56(\mathrm{~d}, 2 \mathrm{H}, \mathrm{J} 6.3, \mathrm{H}-1), 5.59$ (dt, $1 \mathrm{H}, J$ 15.5, 6.6, H-3), 5.80 (dt, 1H, J 15.4, 6.7, H-2); $\delta_{c}\left(150 \mathrm{MHz}, \mathrm{CDCl}_{3}\right) \delta 19.1,19.1,19.2,19.3\left(\mathrm{CH}_{3}\right), 26.6$ (C-5), $28.0\left(\mathrm{CH}_{2} \mathrm{CH}\left(\mathrm{CH}_{3}\right)_{2}\right), 29.8(\mathrm{C}-6), 31.8\left(\mathrm{CHCH}\left(\mathrm{CH}_{3}\right)_{2}\right), 32.2(\mathrm{C}-4), 48.6(\mathrm{C}-7), 51.5\left(\mathrm{COOCH}_{3}\right), 67.7(\mathrm{NHCH})$, 68.6 (C-1), $74.2\left(\mathrm{CH}_{2} \mathrm{CH}\left(\mathrm{CH}_{3}\right)_{2}\right), 123.7$ (C-2), 137.1 (C-3), 155.4 (CO), 175.9 (CO); found: C, 62.77; H, 9.86; N, 4.12. $\mathrm{C}_{18} \mathrm{H}_{33} \mathrm{NO}_{5}$ requires $\mathrm{C}, 62.95 ; \mathrm{H}, 9.68 ; \mathrm{N}, 4.08$.

\section{Typical procedure for the $\mathrm{Pd}^{0 / 11}$-catalysed reaction}

The catalytic system was prepared by stirring $\mathrm{Pd}_{2}(\mathrm{dba})_{3}(22.9 \mathrm{mg}, 0.025 \mathrm{mmol})$ or $\left[\mathrm{PdCl}\left(\mathrm{C}_{3} \mathrm{H}_{5}\right)\right]_{2}(9.1 \mathrm{mg}, 0.025$ $\mathrm{mmol}$ ) and the ligand $(0.055 \mathrm{mmol}$ or $0.11 \mathrm{mmol})$ in an appropriate anhydrous solvent $(3 \mathrm{~mL})$ for $0.5 \mathrm{~h} \mathrm{in} \mathrm{a}$ Schlenk tube under argon. This solution was added, under argon, to a Schlenk tube containing the unsaturated amino carbonate $5 \mathrm{a}-\mathrm{i}(1 \mathrm{mmol})$ in an appropriate anhydrous solvent $(3 \mathrm{~mL})$. The solution was stirred at $25{ }^{\circ} \mathrm{C}$ $\left(0^{\circ} \mathrm{C}\right.$ or $\left.60^{\circ} \mathrm{C}\right)$. After $24 \mathrm{~h}$, removal of the solvent followed by column chromatography gave the corresponding product 6a-i.

(S)-1-((S)-1-Phenylethyl)-2-vinylpiperidine (7a). Colorless oil, 0.21 g, 99\% yield; $\mathrm{R}_{f}(\mathrm{EtOAc} / \mathrm{MeOH} 7: 1) 0.92$; $[\alpha]_{\mathrm{D}}^{20} 40.27$ (c 0.5, $\mathrm{CHCl}_{3}$ ); $v_{\max }$ (liquid film) 3081, 3061, 3027, 2970, 2932, 2854, 2876, 1603, 1600, 1577, 1494, $1450,1447,1186,733,698 \mathrm{~cm}^{-1} ; \delta_{\mathrm{H}}\left(200 \mathrm{MHz}_{\mathrm{CDCl}}\right) 1.24\left(\mathrm{~d}, 3 \mathrm{H}, \mathrm{J} 6.8, \mathrm{CH}_{3} \mathrm{CH}\right), 1.26-1.39(\mathrm{~m}, 2 \mathrm{H}, \mathrm{H}-4, \mathrm{H}-5)$, 1.45-1.55 (m, 2H, H-3, H-5), 1.64-1.71 (m, 2H, H-3, H-4), $2.13(\mathrm{dt}, 1 \mathrm{H}, \mathrm{J}$ 11.6, 2.0, H-6), 2.44 (dt, 1H, J 11.6, 3.9, $\mathrm{H}-6), 3.12\left(\mathrm{dt}, 1 \mathrm{H}, J\right.$ 9.3, 2.6, H-2), 4.14 (q, 1H, J 6.6, $\left.\mathrm{CHC}_{6} \mathrm{H}_{5}\right), 5.07$ (dd, $\left.1 \mathrm{H}, J 10.2,1.5, \mathrm{CHCH}_{2}\right), 5.24(\mathrm{dd}, 1 \mathrm{H}, J$ 17.2, 1.5, $\mathrm{CHCH}_{2}$ ), 5.93 (ddd, $\left.1 \mathrm{H}, J 17.2,10.2,9.2, \mathrm{CHCH}_{2}\right), 7.18\left(\mathrm{t}, 1 \mathrm{H}, J \mathrm{~J} .3, \mathrm{C}_{6} \mathrm{H}_{5}\right), 7.31\left(\mathrm{t}, 2 \mathrm{H}, J \mathrm{~J} .8, \mathrm{C}_{6} \mathrm{H}_{5}\right), 7.44$ (d, 2H, J 7.8, $\left.\mathrm{C}_{6} \mathrm{H}_{5}\right) ; \delta_{\mathrm{c}}\left(50 \mathrm{MHz}, \mathrm{CDCl}_{3}\right) \delta 10.2\left(\mathrm{CH}_{3} \mathrm{CH}\right), 24.0$ (C-4), $26.1(\mathrm{C}-5), 34.1$ (C-3), 44.7 (C-6), 57.0 (CHPh), $63.0(\mathrm{C}-2), 114.9\left(\mathrm{CHCH}_{2}\right), 127.7,127.8,128.3,128.3\left(\mathrm{C}_{6} \mathrm{H}_{5}\right), 139.8\left(\mathrm{CHCH}_{2}\right) ; \mathrm{MS}-\mathrm{El} \mathrm{m} / \mathrm{z}: 216\left(\mathrm{MH}^{+}, 100\right) ; \mathrm{HRMS}$ (EI): $\mathrm{M}^{+}$, found. $215.16709 \mathrm{C}_{15} \mathrm{H}_{21} \mathrm{~N}$ requires 215.16740 .

(R)-1-((R)-1-Phenylethyl)-2-vinylpiperidine (6b). Colorless oil, 0.20 g, 99\% yield; $\mathrm{R}_{f}$ (EtOAc/MeOH $7: 1$ ) 0.92 ; $[\alpha]_{\mathrm{D}}^{20}-42.56\left(\mathrm{c} \mathrm{0.5}, \mathrm{CHCl}_{3}\right) ; v_{\max }$ (liquid film) 3081, 3060, 3022, 2950, 2911, 2871, 2850, 1611, 1580, 1490, 1450, $1439,1182,732,690 \mathrm{~cm}^{-1} ; \delta_{\mathrm{H}}\left(200 \mathrm{MHz}_{\mathrm{CDCl}}\right) 1.26\left(\mathrm{~d}, 3 \mathrm{H}, \mathrm{J} 6.6, \mathrm{CH}_{3} \mathrm{CH}\right), 1.27-1.41(\mathrm{~m}, 2 \mathrm{H}, \mathrm{H}-4, \mathrm{H}-5), 1.46-$ $1.58(\mathrm{~m}, 2 \mathrm{H}, \mathrm{H}-3, \mathrm{H}-5), 1.56-1.74(\mathrm{~m}, 2 \mathrm{H}, \mathrm{H}-3, \mathrm{H}-4), 2.16(\mathrm{dt}, 1 \mathrm{H}, J$ 11.7. 2.8, H-6), 2.45 (dt, 1H, J 11.7, 4.2, H-6), $3.14\left(\mathrm{dt}, 1 \mathrm{H}, J\right.$ 9.2. 2.8, H-2), 4.16 (q, $1 \mathrm{H}, J$ 6.7, $\left.\mathrm{CHC}_{6} \mathrm{H}_{5}\right), 5.09\left(\mathrm{~d}, 1 \mathrm{H}, J 10.1,1.0, \mathrm{CHCH}_{2}\right), 5.25(\mathrm{dd}, 1 \mathrm{H}, J 17.3$, 1.0, $\mathrm{CHCH}_{2}$ ), 5.95 (ddd, $1 \mathrm{H}, J$ 17.3, 10.1, 9.1, $\mathrm{CHCH}_{2}$ ), 7.22 (t, $1 \mathrm{H}, J$ 7.3, $\left.\mathrm{C}_{6} \mathrm{H}_{5}\right), 7.32\left(\mathrm{t}, 2 \mathrm{H}, J \mathrm{~J}, 6, \mathrm{C}_{6} \mathrm{H}_{5}\right), 7.46(\mathrm{~d}$, $2 \mathrm{H}, J$ 7.6, $\left.\mathrm{C}_{6} \mathrm{H}_{5}\right) ; \delta_{\mathrm{c}}\left(50 \mathrm{MHz}, \mathrm{CDCl}_{3}\right) \delta 10.3\left(\mathrm{CH}_{3} \mathrm{CH}\right), 24.0(\mathrm{C}-4), 26.2(\mathrm{C}-5), 34.2(\mathrm{C}-3), 44.8$ (C-6), $57.1(\mathrm{CHPh})$, $63.1(\mathrm{C}-2), 115.0\left(\mathrm{CHCH}_{2}\right), 126.3,127.8,128.5\left(\mathrm{C}_{6} \mathrm{H}_{5}\right), 139.9\left(\mathrm{CHCH}_{2}\right) ; \mathrm{MS}-\mathrm{EI} \mathrm{m} / \mathrm{z}: 214.5\left(\mathrm{MH}^{+}, 100\right) ; \mathrm{HRMS}(\mathrm{El})$ : $\mathrm{M}^{+}$, found 215.16728. $\mathrm{C}_{15} \mathrm{H}_{21} \mathrm{~N}$ requires 215.16740 .

(S)-Methyl 3-phenyl-2-((R)/(S)-2-vinylpiperidin-1-yl)propanoate $(6 \mathrm{c} / 7 \mathrm{c})$. Colorless oil, 99\% (THF, $\left.25^{\circ} \mathrm{C}\right), 99 \%$ $\left(\mathrm{THF}, 55^{\circ} \mathrm{C}\right), 60 \%\left(\mathrm{THF}, 0{ }^{\circ} \mathrm{C}\right), 99 \%\left(\mathrm{CH}_{2} \mathrm{Cl}_{2}, 25^{\circ} \mathrm{C}\right.$ ) yield; $v_{\max }$ (liquid film) 3056, 3022, 2936, 2857, 2809, 1739, 1622, 1600, 1499, 1451, 1435, 1261, 1119, 748, 726, $698 \mathrm{~cm}^{-1}$; MS-EI m/z: $274\left(\mathrm{MH}^{+}, 100\right)$.

(S)-Methyl 3-phenyl-2-((R)-2-vinylpiperidin-1-yl)propanoate $(6 \mathbf{c}) . \mathrm{R}_{f}$ (Hexane/EtOAc, $\left.3: 1\right) 0.83 ;[\alpha]_{\mathrm{D}}^{20}+5.93(c$ $\left.0.5, \mathrm{CHCl}_{3}\right) ; \delta_{\mathrm{H}}\left(600 \mathrm{MHz}, \mathrm{CDCl}_{3}\right)$ 1.30-1.79 (m, 6H, 2H-3, 2H-4, 2H-5), 2.17 (dt, 1H, J 11.6, 2.6, H-6'), 2.86 (dd, 
$1 \mathrm{H}, J$ 13.6, 7.4, $\left.\mathrm{CH}_{2} \mathrm{C}_{6} \mathrm{H}_{5}\right), 3.03\left(\mathrm{dt}, 1 \mathrm{H}, J\right.$ 9.4, 2.6, $\mathrm{H}-6$ '), $3.08\left(\mathrm{dd}, 1 \mathrm{H}, J 13.4,7.4, \mathrm{CH}_{2} \mathrm{C}_{6} \mathrm{H}_{5}\right), 3.08-3.12(\mathrm{~m}, 1 \mathrm{H}, \mathrm{H}-$ 2), $3.67\left(\mathrm{~s}, 3 \mathrm{H}, \mathrm{OCH}_{3}\right), 3.88(\mathrm{t}, 1 \mathrm{H}, J$ 7.5, $\mathrm{CHC}=\mathrm{O}), 5.03\left(\mathrm{dd}, 1 \mathrm{H}, J 10.1,1.9, \mathrm{CHCH}_{2}\right.$ ), 5.15 (dd, 1H, J 17.2, 1.9, $\mathrm{CHCH}_{2}$ ), 5.39 (ddd, $\left.1 \mathrm{H}, J 17.2,10.1,8.9, \mathrm{CHCH}_{2}\right), 7.19-7.23\left(\mathrm{~m}, 2 \mathrm{H}, \mathrm{C}_{6} H_{5}\right), \mathrm{R}_{f} 7.26-7.31\left(\mathrm{~m}, 3 \mathrm{H}, \mathrm{C}_{6} \mathrm{H}_{5}\right) ; \delta_{\mathrm{c}}(150$ $\left.\mathrm{MHz}, \mathrm{CDCl}_{3}\right) \delta$ 23.1, 23.9 (C-4, C-5), 29.1 (C-3), $39.0\left(\mathrm{CH}_{2} \mathrm{C}_{6} \mathrm{H}_{5}\right), 46.7\left(\mathrm{COOCH}_{3}\right), 64.2$ (C-6), 64.9 (C-2), 68.3 $(\mathrm{CHC}=\mathrm{O}), 116.6\left(\mathrm{CHCH}_{2}\right), 126.2,128.9,129.0,129.6,131.0,132.7\left(\mathrm{C}_{6} \mathrm{H}_{5}\right), 141.6\left(\mathrm{CHCH}_{2}\right), 167.9(\mathrm{C}=\mathrm{O}) ; \mathrm{HRMS}$ (EI): $\mathrm{M}^{+}$, found 273.17269. $\mathrm{C}_{17} \mathrm{H}_{23} \mathrm{NO}_{2}$ requires 273.17288 .

(S)-Methyl 3-phenyl-2-((S)-2-vinylpiperidin-1-yl)propanoate (7c). (Hexane/EtOAc, $3: 1) 0.70 ;[\alpha]_{\mathrm{D}}^{20}-48.8(c$ $\left.0.5, \mathrm{CHCl}_{3}\right) ; \delta_{\mathrm{H}}\left(600 \mathrm{MHz}, \mathrm{CDCl}_{3}\right)$ 1.30-1.79 (m, 6H, 2H-3, 2H-4, 2H-5), $2.47\left(\mathrm{dt}, 1 \mathrm{H}, J 11.3,2.8, \mathrm{H}-6^{\prime}\right), 2.96(\mathrm{dt}$, $1 \mathrm{H}, J$ 11.3, 2.8, H-6'), 2.99 (dd, $1 \mathrm{H}, J$ 13.1, 10.3, $\left.\mathrm{CH}_{2} \mathrm{C}_{6} \mathrm{H}_{5}\right), 3.07-3.12\left(\mathrm{~m}, 3 \mathrm{H}, \mathrm{CH}_{2} \mathrm{C}_{6} \mathrm{H}_{5}, \mathrm{H}-2\right), 3.59(\mathrm{~s}, 3 \mathrm{H}, \mathrm{OCH})_{3}$, 3.91 (dd, 1H, J 10.3, 4.1, CHC=0), 5.18 (dd, 1H, J 10.2, 1.8, $\left.\mathrm{CHCH}_{2}\right), 5.28$ (dd,1H, J 17.3, 1.8, $\mathrm{CHCH}_{2}$ ), 5.89 (ddd, $\left.1 \mathrm{H}, J 17.3,10.2,9.0, \mathrm{CHCH}_{2}\right), 7.14-7,20\left(\mathrm{~m}, 3 \mathrm{H}, \mathrm{C}_{6} H_{5}\right), 7.23-7.28\left(\mathrm{~m}, 2 \mathrm{H}, \mathrm{C}_{6} \mathrm{H}_{5}\right) ; \delta_{\mathrm{c}}\left(150 \mathrm{MHz}, \mathrm{CDCl}_{3}\right) \delta 23.1$, 23.9 (C-4, C-5), 30.5 (C-3), $38.9\left(\mathrm{CH}_{2} \mathrm{C}_{6} \mathrm{H}_{5}\right), 47.2\left(\mathrm{COOCH}_{3}\right), 64.3(\mathrm{C}-6), 66.2(\mathrm{C}-2), 68.3(\mathrm{CHC}=0), 116.3\left(\mathrm{CHCH}_{2}\right)$, 126.2, 128.4, 129.0, 129.5, 131.0, $132.7\left(\mathrm{C}_{6} \mathrm{H}_{5}\right), 141.5\left(\mathrm{CHCH}_{2}\right), 167.8(\mathrm{C}=\mathrm{O})$; HRMS (El): $\mathrm{M}^{+}$, found 273.17254. $\mathrm{C}_{17} \mathrm{H}_{23} \mathrm{NO}_{2}$ requires 273.17288 .

(S)-Methyl 3-phenyl-2-((R)/(S)-2-vinylpyrrolidin-1-yl)propanoate (6d/7d). Colorless oil, 99\% (THF, $\left.25^{\circ} \mathrm{C}\right), 98 \%$ $\left(\mathrm{CH}_{2} \mathrm{Cl}_{2}, 25^{\circ} \mathrm{C}\right.$ ) yield; $v_{\max }$ (liquid film) 3056, 3025, 2942, 2870, 1739, 1654, 1603, 1578, 1499, 1442, 1204, 1125, 751, $701 \mathrm{~cm}^{-1}$; MS-EI m/z: $260\left(\mathrm{MH}^{+}, 100\right)$.

(S)-Methyl 3-phenyl-2-((R)-2-vinylpyrrolidin-1-yl)propanoate (6d). (Hexane/EtOAc, $3: 1) 0.81 ;[\alpha]_{\mathrm{D}}^{20}-16.21(c$ $\left.0.5, \mathrm{CHCl}_{3}\right) ; \delta_{\mathrm{H}}\left(600 \mathrm{MHz}, \mathrm{CDCl}_{3}\right)$ 1.25-1.78 (m, 4H, H-3, H-4), 2.13 (ddd, 1H, J 11.7, 9.4, 2.5, H-5), 2.82 (dd, $1 \mathrm{H}, J$ 13.4, 7.4, $\mathrm{CH}_{2} \mathrm{C}_{6} \mathrm{H}_{5}$ ), 3.00 (ddd, $1 \mathrm{H}, J$ 9.4, 7.5, 3.0, $\mathrm{H}-5^{\prime}$ ), 3.05 (dd, $\left.1 \mathrm{H}, J 13.4,7.4, \mathrm{CH}_{2} \mathrm{C}_{6} \mathrm{H}_{5}\right), 3.05-3.09(\mathrm{~m}, 1 \mathrm{H}, \mathrm{H}-$ 2), $3.64\left(\mathrm{~s}, 3 \mathrm{H}, \mathrm{OCH}_{3}\right), 3.85(\mathrm{t}, 1 \mathrm{H}, J$ 7.5, $\mathrm{CHC}=\mathrm{O}), 4.99\left(\mathrm{dd}, 1 \mathrm{H}, J 10.1,1.9, \mathrm{CHCH}_{2}\right), 5.12(\mathrm{dd}, 1 \mathrm{H}, J 17.5,1.9$, $\left.\mathrm{CHCH}_{2}\right), 5.35\left(\mathrm{ddd}, 1 \mathrm{H}, J 17.5,10.1,8.8, \mathrm{CHCH}_{2}\right), 7.15-7.20\left(\mathrm{~m}, 2 \mathrm{H}, \mathrm{C}_{6} \mathrm{H}_{5}\right), 7.23-7.28\left(\mathrm{~m}, 3 \mathrm{H}, \mathrm{C}_{6} \mathrm{H}_{5}\right) ; \delta_{\mathrm{c}}(150$ $\left.\mathrm{MHz}, \mathrm{CDCl}_{3}\right) \delta 23.9(\mathrm{C}-4), 29.1$ (C-3), $38.9\left(\mathrm{CH}_{2} \mathrm{C}_{6} \mathrm{H}_{5}\right), 46.7\left(\mathrm{COOCH}_{3}\right), 50.9(\mathrm{C}-5), 62.5(\mathrm{C}-2), 68.3(\mathrm{CHC}=\mathrm{O}), 116.6$ $\left(\mathrm{CHCH}_{2}\right), 126.4,128.3,129.0,129.2,131.0,140.7\left(\mathrm{C}_{6} \mathrm{H}_{5}\right), 132.7\left(\mathrm{CHCH}_{2}\right), 167.9(\mathrm{C}=\mathrm{O})$; HRMS (EI): $\mathrm{M}^{+}$, found 259.15708. $\mathrm{C}_{16} \mathrm{H}_{21} \mathrm{NO}_{2}$ requires 259.15723.

(S)-Methyl 3-phenyl-2-((S)-2-vinylpyrrolidin-1-yl)propanoate (7d). (Hexane/EtOAc, $3: 1) 0.65 ;[\alpha]_{\mathrm{D}}^{20}-8.13$ (c 1, $\left.\mathrm{CHCl}_{3}\right) ; \delta_{\mathrm{H}}\left(600 \mathrm{MHz}, \mathrm{CDCl}_{3}\right)$ 1.46-1.74 (m, 4H, H-3, H-4), 2.44 (ddd, 1H, J 2.8, 9.8, 7.5, H-5), 2.91 (ddd, 1H, J 4.0, 11.9, 9.8, H-5), 2.96 (dd, $\left.1 \mathrm{H}, J 13.1,10.3, \mathrm{CH}_{2} \mathrm{C}_{6} \mathrm{H}_{5}\right), 3.03-3.08\left(\mathrm{~m}, 2 \mathrm{H}, \mathrm{H}-2, \mathrm{CH}_{2} \mathrm{C}_{6} \mathrm{H}_{5}\right), 3.56(\mathrm{~s}, 3 \mathrm{H}, \mathrm{OCH})_{3}, 3.88$ (dd, $1 \mathrm{H}, J$ 10.3, 4.1, CHC=O), 5.15 (dd, $\left.1 \mathrm{H}, J 10.1,1.8, \mathrm{CHCH}_{2}\right), 5.24\left(\mathrm{dd}, 1 \mathrm{H}, J 17.5,1.8, \mathrm{CHCH}_{2}\right), 5.86(\mathrm{ddd}, 1 \mathrm{H}, J$ 17.5, 10.1, 9.0, $\left.\mathrm{CHCH}_{2}\right), 7.12-7.17\left(\mathrm{~m}, 1 \mathrm{H}, \mathrm{C}_{6} \mathrm{H}_{5}\right), 7.20-7.24\left(\mathrm{~m}, 1 \mathrm{H}, \mathrm{C}_{6} \mathrm{H}_{5}\right), 7.30-7.44\left(\mathrm{~m}, 3 \mathrm{H}, \mathrm{C}_{6} \mathrm{H}_{5}\right) ; \delta_{\mathrm{c}}(150 \mathrm{MHz}$, $\left.\mathrm{CDCl}_{3}\right) 23.0$ (C-4), 30.6 (C-3), $37.7\left(\mathrm{CH}_{2} \mathrm{C}_{6} \mathrm{H}_{5}\right), 46.7\left(\mathrm{COOCH}_{3}\right), 50.9(\mathrm{C}-5), 65.1$ (C-2), $65.7(\mathrm{CHC}=0), 116.6$ $\left(\mathrm{CHCH}_{2}\right), 128.3,128.9,129.0,129.6,131.0,138.8\left(\mathrm{C}_{6} \mathrm{H}_{5}\right), 132.6\left(\mathrm{CHCH}_{2}\right), 167.8(\mathrm{C}=\mathrm{O})$; HRMS (EI): $\mathrm{M}^{+}$, found 259.15711. $\mathrm{C}_{16} \mathrm{H}_{21} \mathrm{NO}_{2}$ requires 259.15723.

(S)-Methyl 2-((R)/(S)-2-vinylpyrrolidin-1-yl)propanoate $(6 \mathrm{e} / 7 \mathrm{e})$. Colorless oil, $97 \%\left(\mathrm{THF}, 55{ }^{\circ} \mathrm{C}\right), 98 \%\left(\mathrm{CH}_{2} \mathrm{Cl}\right.$, $35^{\circ} \mathrm{C}$ ) yield; $v_{\max }$ (liquid film) 3053, 2965, 2873, 1733, 1651, 1261, $1192 \mathrm{~cm}^{-1}$; MS-El m/z: $184\left(\mathrm{MH}^{+}, 100\right)$; HRMS (EI): $\mathrm{M}^{+}$, found 183.12591. $\mathrm{C}_{10} \mathrm{H}_{17} \mathrm{NO}_{2}$ requires 183.12593.

(S)-Methyl 2-((R)-2-vinylpyrrolidin-1-yl)propanoate (6e). $\delta_{\mathrm{H}}\left(600 \mathrm{MHz}, \mathrm{CDCl}_{3}\right) 1.26\left(\mathrm{~d}, 3 \mathrm{H}, J 7.2, \mathrm{CHCH}_{3}\right), 1.45$ $1.70(\mathrm{~m}, 4 \mathrm{H}, \mathrm{H}-3, \mathrm{H}-4), 2.73$ (q, 1H, J 8.5, H-5), 2.94-2.97 (m, 1H, H-5), $3.16(\mathrm{q}, 1 \mathrm{H}, J \mathrm{~J} .9, \mathrm{H}-2), 3.51$ (q, 1H, J 7.2, $\left.\mathrm{CHCH}_{3}\right), 3.59\left(\mathrm{~s}, 3 \mathrm{H}, \mathrm{COOCH}_{3}\right), 4.94\left(\mathrm{dd}, 1 \mathrm{H}, J\right.$ 10.0, 1.9, $\left.\mathrm{CH}=\mathrm{CH}_{2}\right), 5.03\left(\mathrm{dd}, 1 \mathrm{H}, J\right.$ 18.5, 1.9, $\left.\mathrm{CHCH}_{2}\right), 5.56(\mathrm{ddd}$, $1 \mathrm{H}, J$ 18.2, 10.0, 8.3, $\left.\mathrm{CHCH}_{2}\right) ; \delta_{\mathrm{C}}\left(150 \mathrm{MHz}, \mathrm{CDCl}_{3}\right) \delta 17.3\left(\mathrm{CHCH}_{3}\right), 22.8$ (C-4), 32.2 (C-3), 46.8 (C-5), 51.0 $\left(\mathrm{COOCH}_{3}\right), 55.8\left(\mathrm{CHCH}_{3}\right), 65.8(\mathrm{C}-2), 116.4\left(\mathrm{CHCH}_{2}\right), 140.9\left(\mathrm{CHCH}_{2}\right), 174.1(\mathrm{C}=\mathrm{O})$.

(S)-Methyl 2-((S)-2-vinylpyrrolidin-1-yl)propanoate (7e). $\delta_{\mathrm{H}}\left(600 \mathrm{MHz}, \mathrm{CDCl}_{3}\right) 1.18\left(\mathrm{~d}, 3 \mathrm{H}, \mathrm{J} 6.9, \mathrm{CHCH}_{3}\right), 1.45-$ $1.70(\mathrm{~m}, 4 \mathrm{H}, \mathrm{H}-3, \mathrm{H}-4), 2.43$ (q, 1H, J 8.5, H-5), 2.97-2.99 (m, 1H, H-5), 3.03 (q, 1H, J 7.8, H-2), 3.54 (q, 1H, J 6.9, $\left.\mathrm{CHCH}_{3}\right), 3.60\left(\mathrm{~s}, 3 \mathrm{H}, \mathrm{COOCH}_{3}\right), 4.99$ (dd, $1 \mathrm{H}, J$ 10.0, 1.9, $\left.\mathrm{CH}=\mathrm{CH}_{2}\right), 5.06$ (dd, 1H, J 18.5, 1.9, $\mathrm{CHCH}_{2}$ ), 5.64 (ddd, 
$1 \mathrm{H}, J$ 18.5, 10.0, 8.6, $\left.\mathrm{CHCH}_{2}\right) ; \delta_{\mathrm{C}}\left(150 \mathrm{MHz}, \mathrm{CDCl}_{3}\right) 14.1\left(\mathrm{CHCH}_{3}\right), 22.5$ (C-4), 32.1 (C-3), 49.4 (C-5), 51.6 $\left(\mathrm{COOCH}_{3}\right), 58.9\left(\mathrm{CHCH}_{3}\right), 64.9(\mathrm{C}-2), 115.7\left(\mathrm{CHCH}_{2}\right), 141.2\left(\mathrm{CHCH}_{2}\right), 174.9(\mathrm{C}=0)$.

(S)-Methyl 2-((R)/(S)-2-vinylpiperidin-1-yl)propanoate (6f/7f). Colorless oil, $99 \%$ (THF, $\left.25{ }^{\circ} \mathrm{C}\right), 99 \%\left(\mathrm{CH}_{2} \mathrm{Cl}_{2}, 25\right.$ ${ }^{\circ} \mathrm{C}$ ) yield; $v_{\max }$ (liquid film) 3060, 2958, 2927, 2854, 1736, 1654, 1258, $1122 \mathrm{~cm}^{-1}$; MS-El m/z: $198\left(\mathrm{MH}^{+}, 100\right)$; HRMS (EI): $\mathrm{M}^{+}$, found 197.14155. $\mathrm{C}_{11} \mathrm{H}_{19} \mathrm{NO}_{2}$ requires 197.14158.

(S)-Methyl 2-((R)-2-vinylpiperidin-1-yl)propanoate (6f). $\delta_{\mathrm{H}}\left(600 \mathrm{MHz}, \mathrm{CDCl}_{3}\right) 1.19$ (d, 3H, J 7.10, $\left.\mathrm{CHCH}_{3}\right), 1.20$ 1.65 (m, 6H, H-3, H-4, H-5), 2.15-2.23 (m, 1H, H-6), 2.89 (d, 1H, J 11.2, H-6), 3.04 (dd, 1H, J 10.7, 2.5, H-2), 3.59 (s, $\left.3 \mathrm{H}, \mathrm{COOCH}_{3}\right), 3.70$ (q, $\left.1 \mathrm{H}, J \mathrm{~J} .6, \mathrm{CHCH}_{3}\right), 5.00$ (dd, $\left.1 \mathrm{H}, J 10.1,1.8, \mathrm{CHCH}_{2}\right), 5.12$ (dd, $1 \mathrm{H}, J 17.2,1.8, \mathrm{CHCH}_{2}$ ), 5.61 (ddd, $1 \mathrm{H}, J$ 17.2, 10.1, 9.6, $\left.\mathrm{CHCH}_{2}\right) ; \delta \mathrm{c}\left(150 \mathrm{MHz}, \mathrm{CDCl}_{3}\right) \delta 19.0\left(\mathrm{CHCH}_{3}\right), 24.4$ and 26.5 (C-4 and C-5), 34.3 (C-3), $45.9(\mathrm{C}-6), 50.8\left(\mathrm{COOCH}_{3}\right), 57.4\left(\mathrm{CHCH}_{3}\right), 64.8(\mathrm{C}-2), 116.6\left(\mathrm{CHCH}_{2}\right), 141.6\left(\mathrm{CHCH}_{2}\right), 173.7(\mathrm{C}=0)$.

(S)-Methyl 2-(S)-2-vinylpiperidin-1-yl)propanoate (7f). $\delta_{\mathrm{H}}\left(600 \mathrm{MHz}, \mathrm{CDCl}_{3}\right) 1.06$ (d, 3H, J 7.0, $\left.\mathrm{CHCH}_{3}\right), 1.20$ 1.65 (m, 6H, H-3, H-4, H-5), 2.15-2.23 (m, 1H, H-6), 2.70 (dt, 1H, J 11.2, 3.1, H-6), 2.81 (ddd, $1 \mathrm{H}, J$ J 10.7, 9.5, 3.1, $\mathrm{H}-2), 3.62\left(\mathrm{~s}, 3 \mathrm{H}, \mathrm{COOCH}_{3}\right), 3.72\left(\mathrm{q}, 1 \mathrm{H}, \mathrm{J} 7.0, \mathrm{CHCH}_{3}\right), 4.98$ (dd, $\left.1 \mathrm{H}, \mathrm{J} 10.1,1.7, \mathrm{CHCH}_{2}\right), 5.09$ (dd, $1 \mathrm{H}, J$ J 17.1, 1.7, $\left.\mathrm{CHCH}_{2}\right), 5.72$ (ddd, $\left.1 \mathrm{H}, J 17.1,10.1,1.9, \mathrm{CHCH}_{2}\right) ; \delta_{\mathrm{C}}\left(150 \mathrm{MHz}, \mathrm{CDCl}_{3}\right) 16.1\left(\mathrm{CHCH}_{3}\right), 24.1$ and $26.0(\mathrm{C}-4$ and $\mathrm{C}-5)$, $33.7(\mathrm{C}-3), 47.0(\mathrm{C}-6), 51.9\left(\mathrm{COOCH}_{3}\right), 58.7\left(\mathrm{CHCH}_{3}\right), 63.8(\mathrm{C}-2), 116.1\left(\mathrm{CHCH}_{2}\right), 141.2\left(\mathrm{CHCH}_{2}\right), 174.8(\mathrm{C}=0)$.

(S)-Methyl 4-methyl-2-((R)/(S)-2-vinylpyrrolidin-1-yl)pentanoate $(6 \mathrm{~g} / 7 \mathrm{~g})$. Colorless oil, $98 \%\left(\mathrm{THF}, 2{ }^{\circ} \mathrm{C}\right), 97 \%$ $\left(\mathrm{CH}_{2} \mathrm{Cl}_{2}, 25^{\circ} \mathrm{C}\right.$ ) yield; $v_{\max }$ (liquid film) 3053, 2952, 2923, 2873, 1733, 1651, 1195, $1122 \mathrm{~cm}^{-1} ; \mathrm{MS}-\mathrm{El} \mathrm{m} / \mathrm{z}: 226$ $\left(\mathrm{MH}^{+}, 100\right) ; \mathrm{HRMS}(\mathrm{EI}): \mathrm{M}^{+}$, found 225.17282. $\mathrm{C}_{13} \mathrm{H}_{23} \mathrm{NO}_{2}$ requires 225.17288 .

(S)-Methyl 4-methyl-2-((R)-2-vinylpyrrolidin-1-yl)pentanoate $(6 \mathrm{~g})$. $\delta_{\mathrm{H}}\left(600 \mathrm{MHz}, \mathrm{CDCl}_{3}\right) 0.79$ (d, 3H, J 6.7, $\left.\mathrm{CHCH}_{2} \mathrm{CH}\left(\mathrm{CH}_{3}\right)_{2}\right), 0.83$ (d, 3H, J 6.7, $\left.\mathrm{CHCH}_{2} \mathrm{CH}\left(\mathrm{CH}_{3}\right)_{2}\right), 1.30-1.90\left(\mathrm{~m}, 7 \mathrm{H}, \mathrm{H}-3, \mathrm{H}-4, \mathrm{CHCH}_{2} \mathrm{CH}\left(\mathrm{CH}_{3}\right)_{2}\right), 2.77$ (q, $1 \mathrm{H}, \mathrm{J}$

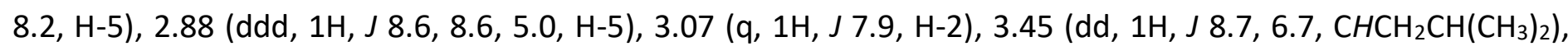
$3.60\left(\mathrm{~s}, 3 \mathrm{H}, \mathrm{COOCH}_{3}\right), 5.01$ (dd, $\left.1 \mathrm{H}, \mathrm{J} 10.0,1.8, \mathrm{CHCH}_{2}\right), 5.06$ (dd, $\left.1 \mathrm{H}, \mathrm{J} 17.4,1.6, \mathrm{CHCH}_{2}\right), 5.52$ (ddd, $1 \mathrm{H}, \mathrm{J}$ 17.4, 10.0, 8.6, $\left.\mathrm{CHCH}_{2}\right) ; \delta_{\mathrm{C}}\left(150 \mathrm{MHz}, \mathrm{CDCl}_{3}\right) \delta 22.1\left(\mathrm{CHCH}_{2} \mathrm{CH}\left(\mathrm{CH}_{3}\right)_{2}\right), 23.1(\mathrm{C}-4), 24.9\left(\mathrm{CHCH}_{2} \mathrm{CH}\left(\mathrm{CH}_{3}\right)_{2}\right), 32.3(\mathrm{C}-3)$, $40.2\left(\mathrm{CHCH}_{2} \mathrm{CH}\left(\mathrm{CH}_{3}\right)_{2}\right), 46.1(\mathrm{C}-5), 50.8\left(\mathrm{COOCH}_{3}\right), 58.3\left(\mathrm{CHCH}_{2} \mathrm{CH}\left(\mathrm{CH}_{3}\right)_{2}\right), 65.0(\mathrm{C}-2), 116.5\left(\mathrm{CHCH}_{2}\right), 141.8$ $\left(\mathrm{CHCH}_{2}\right), 174.3(\mathrm{C}=\mathrm{O})$.

(S)-Methyl 4-methyl-2-((S)-2-vinylpyrrolidin-1-yl)pentanoate (7g). $\delta_{\mathrm{H}}\left(600 \mathrm{MHz}, \mathrm{CDCl}_{3}\right) 0.81$ (d, 3H, J 6.9, $\left.\mathrm{CHCH}_{2} \mathrm{CH}\left(\mathrm{CH}_{3}\right)_{2}\right), 0.82$ (d, 3H, J 6.9, $\left.\mathrm{CHCH}_{2} \mathrm{CH}\left(\mathrm{CH}_{3}\right)_{2}\right), 1.30-1.90\left(\mathrm{~m}, 7 \mathrm{H}, \mathrm{H}-3, \mathrm{H}-4, \mathrm{CHCH}_{2} \mathrm{CH}\left(\mathrm{CH}_{3}\right)_{2}\right), 2.49$ (q, $1 \mathrm{H}, \mathrm{J}$

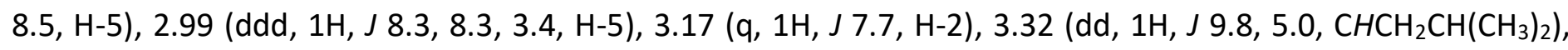
3.59 (s, 3H, $\left.\mathrm{COOCH}_{3}\right), 4.92$ (dd, $\left.1 \mathrm{H}, J 10.1,1.4, \mathrm{CHCH}_{2}\right), 5.00$ (dd, $1 \mathrm{H}, J 17.3,1.0, \mathrm{CHCH}_{2}$ ), 5.63 (ddd, $1 \mathrm{H}, J$ J 17.3, 10.1, 9.1, $\left.\mathrm{CHCH}_{2}\right) ; \delta_{\mathrm{C}}\left(150 \mathrm{MHz}, \mathrm{CDCl}_{3}\right) 22.2\left(\mathrm{CHCH}_{2} \mathrm{CH}\left(\mathrm{CH}_{3}\right)_{2}\right), 23.0(\mathrm{C}-4), 25.4\left(\mathrm{CHCH}_{2} \mathrm{CH}\left(\mathrm{CH}_{3}\right)_{2}\right), 32.3$ (C-3), 37.9 $\left(\mathrm{CHCH}_{2} \mathrm{CH}\left(\mathrm{CH}_{3}\right)_{2}\right), 50.2(\mathrm{C}-5), 51.3\left(\mathrm{COOCH}_{3}\right), 62.2\left(\mathrm{CHCH}_{2} \mathrm{CH}\left(\mathrm{CH}_{3}\right)_{2}\right), 65.0(\mathrm{C}-2), 115.2\left(\mathrm{CHCH}_{2}\right), 143.5\left(\mathrm{CHCH}_{2}\right)$, $174.4(\mathrm{C}=\mathrm{O})$.

(S)-Methyl 4-methyl-2-((R)/(S)-2-vinylpiperidin-1-yl)pentanoate (6h/7h). Colorless oil, $98 \%\left(\mathrm{THF}, 55^{\circ} \mathrm{C}\right), 98 \%$ $\left(\mathrm{CH}_{2} \mathrm{Cl}_{2}, 35^{\circ} \mathrm{C}\right.$ ) yield; $v_{\max }$ (liquid film) 3056, 2961, 2936, 2873, 1739, 1261, $1097 \mathrm{~cm}^{-1} ; \mathrm{MS}-\mathrm{El} \mathrm{m} / \mathrm{z}: 240\left(\mathrm{MH}^{+}\right.$, 100); HRMS (EI): $\mathrm{M}^{+}$, found 239.18847. $\mathrm{C}_{14} \mathrm{H}_{25} \mathrm{NO}_{2}$ requires 239.18843.

(S)-Methyl 4-methyl-2-((R)-2-vinylpiperidin-1-yl)pentanoate (6h). $\delta_{\mathrm{H}}\left(600 \mathrm{MHz}, \mathrm{CDCl}_{3}\right) 0.73$ (d, 3H, J 6.6,

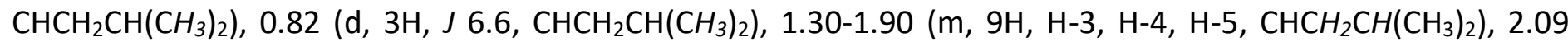
(ddd, $1 \mathrm{H}, J 11.8,11.2,2.3, \mathrm{H}-6), 2.86-2.98(\mathrm{~m}, 2 \mathrm{H}, \mathrm{H}-2, \mathrm{H}-6), 3.57\left(\mathrm{~s}, 3 \mathrm{H}, \mathrm{COOCH}_{3}\right), 3.61(\mathrm{dd}, 1 \mathrm{H}, J$ 9.8, 6.7, $\left.\mathrm{CHCH}_{2} \mathrm{CH}\left(\mathrm{CH}_{3}\right)_{2}\right), 5.01$ (dd, $1 \mathrm{H}, J$ J 10.0, 1.5, $\left.\mathrm{CHCH}_{2}\right), 5.10$ (dd, $\left.1 \mathrm{H}, J 17.2,1.6, \mathrm{CHCH}_{2}\right), 5.54$ (ddd, $1 \mathrm{H}, J$ J 17.2, 10.0,

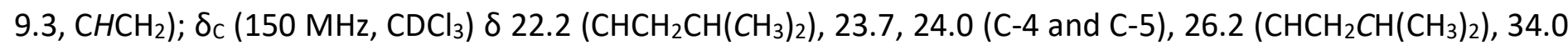
$(\mathrm{C}-3), 39.0\left(\mathrm{CHCH}_{2} \mathrm{CH}\left(\mathrm{CH}_{3}\right)_{2}\right), 46.6(\mathrm{C}-6), 51.6\left(\mathrm{COOCH}_{3}\right), 65.7\left(\mathrm{CHCH}_{2} \mathrm{CH}\left(\mathrm{CH}_{3}\right)_{2}\right), 68.3(\mathrm{C}-2), 116.0\left(\mathrm{CHCH}_{2}\right), 140.0$ $\left(\mathrm{CHCH}_{2}\right), 174.4(\mathrm{C}=\mathrm{O})$.

(S)-Methyl 4-methyl-2-((S)-2-vinylpiperidin-1-yl)pentanoate (7h). $\delta_{\mathrm{H}}\left(600 \mathrm{MHz}, \mathrm{CDCl}_{3}\right) 0.78$ (d, 3H, J 6.6, $\left.\mathrm{CHCH}_{2} \mathrm{CH}\left(\mathrm{CH}_{3}\right)_{2}\right), 0.85\left(\mathrm{~d}, 3 \mathrm{H}, \mathrm{J}\right.$ 6.6, $\left.\mathrm{CHCH}_{2} \mathrm{CH}\left(\mathrm{CH}_{3}\right)_{2}\right), 1.25-1.70\left(\mathrm{~m}, 9 \mathrm{H}, \mathrm{H}-3, \mathrm{H}-4, \mathrm{H}-5, \mathrm{CHCH}_{2} \mathrm{CH}_{(}\left(\mathrm{CH}_{3}\right)_{2}\right), 2.27$ 
(ddd, 1H, J 11.6, 11.0, 2.9, H-6), 2.83 (dt, 1H, J 11.6, 2.9, H-6), 2.86-2.98 (m, 1H, H-2), 3.55 (dd, 1H, J 10.4, 4.0, $\left.\mathrm{CHCH}_{2} \mathrm{CH}\left(\mathrm{CH}_{3}\right)_{2}\right), 3.61\left(\mathrm{~s}, 3 \mathrm{H}, \mathrm{COOCH}_{3}\right), 5.00\left(\mathrm{dd}, 1 \mathrm{H}, \mathrm{J} 10.4,1.5, \mathrm{CHCH}_{2}\right), 5.05$ (dd, $1 \mathrm{H}, J$ J 17.3, 1.0, $\left.\mathrm{CHCH}_{2}\right), 5.78$ (ddd, $1 \mathrm{H}, J$ 17.3, 10.4, 9.4, $\left.\mathrm{CHCH}_{2}\right) ; \delta_{\mathrm{C}}\left(150 \mathrm{MHz}, \mathrm{CDCl}_{3}\right) 22.2\left(\mathrm{CHCH}_{2} \mathrm{CH}\left(\mathrm{CH}_{3}\right)_{2}\right), 23.6,23.7$ (C-4 and C-5), 25.8 $\left(\mathrm{CHCH}_{2} \mathrm{CH}\left(\mathrm{CH}_{3}\right)_{2}\right), 33.4$ (C-3), $39.0\left(\mathrm{CHCH}_{2} \mathrm{CH}\left(\mathrm{CH}_{3}\right)_{2}\right), 46.6(\mathrm{C}-6), 51.6\left(\mathrm{COOCH}_{3}\right), 62.2\left(\mathrm{CHCH}_{2} \mathrm{CH}\left(\mathrm{CH}_{3}\right)_{2}\right), 64.2(\mathrm{C}-$ 2), $116.0\left(\mathrm{CHCH}_{2}\right), 141.3\left(\mathrm{CHCH}_{2}\right), 174.4(\mathrm{C}=\mathrm{O})$.

(S)-Methyl 3-methyl-2-((R)/(S)-2-vinylpyrrolidin-1-yl)butanoate (6i/7i). Colorless oil, 99\% (THF, $\left.25{ }^{\circ} \mathrm{C}\right)$ yield; $V_{\max }$ (liquid film) 3060, 2958, 2926, 2870, 1731, 1621, 1267, $1194 \mathrm{~cm}^{-1} ; \mathrm{MS}-\mathrm{EI} \mathrm{m} / \mathrm{z}$ : 212 (MH+, 100); HRMS (EI): $\mathrm{M}^{+}$, found 211.15715. $\mathrm{C}_{12} \mathrm{H}_{21} \mathrm{NO}_{2}$ requires 211.15723 .

(S)-Methyl 3-methyl-2-((R)-2-vinylpyrrolidin-1-yl)butanoate (6i). $\delta_{\mathrm{H}}\left(600 \mathrm{MHz}, \mathrm{CDCl}_{3}\right) 0.85$ (d, 3H, J 6.6, $\left.\mathrm{CHCH}\left(\mathrm{CH}_{3}\right)_{2}\right), 0.96\left(\mathrm{~d}, 3 \mathrm{H}, J\right.$ 6.6, $\left.\mathrm{CHCH}\left(\mathrm{CH}_{3}\right)_{2}\right), 1.88-1.95(\mathrm{~m}, 2 \mathrm{H}, \mathrm{H}-3), 1.75-1.83(\mathrm{~m}, 2 \mathrm{H}, \mathrm{H}-4), 2.08-2.16(\mathrm{~m}, 1 \mathrm{H}$, $\mathrm{CHCH}\left(\mathrm{CH}_{3}\right)_{2}$ ), 2.80 (q, 1H, J 8.2, H-5), 2.92 (ddd, 1H, J 8.2, 7.9, 4.3, H-5), 2.89-3.10 (m, 2H, H-2, $\left.\mathrm{CHCH}\left(\mathrm{CH}_{3}\right)_{2}\right)$, $3.67\left(\mathrm{~s}, 3 \mathrm{H}, \mathrm{COOCH}_{3}\right), 5.08\left(\mathrm{dd}, 1 \mathrm{H}, \mathrm{J}\right.$ 10.0, 1.8, $\left.\mathrm{CHCH}_{2}\right), 5.15$ (dd, 1H, J 17.0, 1.6, $\left.\mathrm{CHCH}_{2}\right), 5.56$ (ddd, 1H, J 17.0,

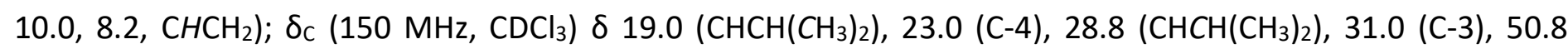
$\left(\mathrm{COOCH}_{3}\right), 45.9(\mathrm{C}-5), 64.9\left(\mathrm{CHCH}\left(\mathrm{CH}_{3}\right)_{2}\right), 67.5(\mathrm{C}-2), 116.0\left(\mathrm{CHCH}_{2}\right), 143.5\left(\mathrm{CHCH}_{2}\right), 172.2(\mathrm{C}=\mathrm{O})$.

(S)-Methyl 3-methyl-2-((S)-2-vinylpyrrolidin-1-yl)butanoate (7i). $\delta_{\mathrm{H}}\left(600 \mathrm{MHz}, \mathrm{CDCl}_{3}\right) 0.88$ (d, 3H, J 6.7, $\left.\mathrm{CHCH}\left(\mathrm{CH}_{3}\right)_{2}\right), 0.95$ (d, 3H, J 6.7, $\left.\mathrm{CHCH}\left(\mathrm{CH}_{3}\right)_{2}\right), 1.50-1.60(\mathrm{~m}, 2 \mathrm{H}, \mathrm{H}-3), 1.63-1.74(\mathrm{~m}, 2 \mathrm{H}, \mathrm{H}-4), 2.08-2.16(\mathrm{~m}, 1 \mathrm{H}$, $\left.\mathrm{CHCH}\left(\mathrm{CH}_{3}\right)_{2}\right), 2.62(\mathrm{q}, 1 \mathrm{H}, J$ 8.4, H-5), 2.89-3.10 (m, 1H, H-2), 3.08 (ddd, $1 \mathrm{H}, J$ 8.4, 8.2, 3.6, H-5), $3.38(\mathrm{dd}, 1 \mathrm{H}, J$ 8.1, 7.9, $\left.\mathrm{CHCH}\left(\mathrm{CH}_{3}\right)_{2}\right), 3.65$ (s, 3H, $\left.\mathrm{COOCH}_{3}\right), 4.94$ (dd, $\left.1 \mathrm{H}, \mathrm{J} 10.0,1.6, \mathrm{CHCH}_{2}\right), 5.06$ (dd, 1H, J 17.4, 1.1, $\left.\mathrm{CHCH}_{2}\right)$, 5.71 (ddd, $1 \mathrm{H}, J$ 17.4, 10.0, 8.7, $\left.\left.\mathrm{CHCH}_{2}\right) ; \delta_{\mathrm{c}}\left(150 \mathrm{MHz}, \mathrm{CDCl}_{3}\right) 20.4\left(\mathrm{CHCH}\left(\mathrm{CH}_{3}\right)_{2}\right), 23.0(\mathrm{C}-4), 31.5\left(\mathrm{CHCH}_{(\mathrm{CH}}\right)_{2}\right)$, $32.6(\mathrm{C}-3), 50.4\left(\mathrm{COOCH}_{3}\right), 50.8(\mathrm{C}-5), 65.1\left(\mathrm{CHCH}\left(\mathrm{CH}_{3}\right)_{2}\right), 70.7(\mathrm{C}-2), 114.4\left(\mathrm{CHCH}_{2}\right), 142.0\left(\mathrm{CHCH}_{2}\right), 173.5$ $(\mathrm{C}=\mathrm{O})$.

(S)-Methyl 3-methyl-2-((R)/(S)-2-vinylpiperidin-1-yl)butanoate $(6 \mathbf{6 j} / 7 \mathbf{j})$. Colorless oil, 98\% (THF, $\left.25^{\circ} \mathrm{C}\right)$ yield; $v_{\max }$ (liquid film) 3060, 2961, 2930, 2873, 1733, 1622, 1268, $1192 \mathrm{~cm}^{-1} ; \mathrm{MS}-\mathrm{El} \mathrm{m} / \mathrm{z}: 226$ (MH+, 100); HRMS (EI): $\mathrm{M}^{+}$, found 225.17279. $\mathrm{C}_{13} \mathrm{H}_{23} \mathrm{NO}_{2}$ requires 225.17288 .

(S)-Methyl 3-methyl-2-((R)-2-vinylpiperidin-1-yl)butanoate (6j). $\mathrm{c}_{\mathrm{H}}\left(600 \mathrm{MHz}, \mathrm{CDCl}_{3}\right) 0.85$ (d, 3H, J 6.7, $\left.\mathrm{CHCH}\left(\mathrm{CH}_{3}\right)_{2}\right), 0.90\left(\mathrm{~d}, 3 \mathrm{H}, J\right.$ 6.7, $\left.\mathrm{CHCH}\left(\mathrm{CH}_{3}\right)_{2}\right), 1.30-1.90(\mathrm{~m}, 6 \mathrm{H}, \mathrm{H}-3, \mathrm{H}-4, \mathrm{H}-5), 1.90-2.10\left(\mathrm{~m}, 1 \mathrm{H}, \mathrm{CHCH}\left(\mathrm{CH}_{3}\right)_{2}\right)$, 2.55-2.59 (m, $1 \mathrm{H}, \mathrm{H}-6), 2.74-2.85(\mathrm{~m}, 2 \mathrm{H}, \mathrm{H}-2, \mathrm{H}-6), 3.04\left(\mathrm{~d}, 1 \mathrm{H}, J\right.$ 7.6, $\left.\mathrm{CHCH}\left(\mathrm{CH}_{3}\right)_{2}\right), 3.53\left(\mathrm{~s}, 3 \mathrm{H}, \mathrm{COOCH}_{3}\right), 5.02$ (dd, 1H, J 10.1, 1.7, $\mathrm{CHCH}_{2}$ ), 5.11 (dd, $1 \mathrm{H}, J$ 18.8, 1.0, $\mathrm{CHCH}_{2}$ ), 5.52 (ddd, $1 \mathrm{H}, J$ 18.8, 10.1, 8.9, $\left.\mathrm{CHCH}_{2}\right) ; \delta \mathrm{C}(150$ $\left.\mathrm{MHz}, \mathrm{CDCl}_{3}\right) \delta 19.8\left(\mathrm{CHCH}\left(\mathrm{CH}_{3}\right)_{2}\right), 26.5,27.9(\mathrm{C}-4, \mathrm{C}-5), 31.5\left(\mathrm{CHCH}\left(\mathrm{CH}_{3}\right)_{2}\right), 33.8(\mathrm{C}-3), 44.3(\mathrm{C}-6), 52.2$ $\left(\mathrm{COOCH}_{3}\right), 64.8(\mathrm{C}-2), 71.7\left(\mathrm{CHCH}\left(\mathrm{CH}_{3}\right)_{2}\right), 115.7\left(\mathrm{CHCH}_{2}\right), 143.5\left(\mathrm{CHCH}_{2}\right), 177.5(\mathrm{C}=0)$.

(S)-Methyl 3-methyl-2-((S)-2-vinylpiperidin-1-yl)butanoate (7j). $\delta_{\mathrm{H}}\left(600 \mathrm{MHz}, \mathrm{CDCl}_{3}\right) 0.85$ ( d, 3H, J 6.7, $\left.\mathrm{CHCH}\left(\mathrm{CH}_{3}\right)_{2}\right), 0.90\left(\mathrm{~d}, 3 \mathrm{H}, \mathrm{J} 6.7, \mathrm{CHCH}\left(\mathrm{CH}_{3}\right)_{2}\right), 1.30-1.90(\mathrm{~m}, 6 \mathrm{H}, \mathrm{H}-3, \mathrm{H}-4, \mathrm{H}-5), 1.90-2.10\left(\mathrm{~m}, 1 \mathrm{H}, \mathrm{CHCH}\left(\mathrm{CH}_{3}\right)_{2}\right)$, 2.55-2.59 (m, 1H, H-6), $2.91\left(\mathrm{~d}, 1 \mathrm{H}, J\right.$ 7.4, $\left.\mathrm{CHCH}\left(\mathrm{CH}_{3}\right)_{2}\right), 2.97$ (ddd, $\left.1 \mathrm{H}, J 11.7,8.0,3.5, \mathrm{H}-6\right), 3.13-3.18(\mathrm{~m}, 1 \mathrm{H}, \mathrm{H}-$ 2), $3.67\left(\mathrm{~s}, 3 \mathrm{H}, \mathrm{COOCH}_{3}\right), 4.99\left(\mathrm{dd}, 1 \mathrm{H}, J 10.3,1.6, \mathrm{CHCH}_{2}\right), 5.09$ (dd, 1H, J 18.8, 1.7, $\left.\mathrm{CHCH}_{2}\right), 5.96(\mathrm{ddd}, 1 \mathrm{H}, J$ 18.8, 10.3, 9.1, $\left.\left.\mathrm{CHCH}_{2}\right) ; \delta_{\mathrm{c}}\left(150 \mathrm{MHz}, \mathrm{CDCl}_{3}\right) \delta 20.4\left(\mathrm{CHCH}\left(\mathrm{CH}_{3}\right)_{2}\right), 26.7(\mathrm{C}-4), 27.9(\mathrm{C}-5), 28.2\left(\mathrm{CHCH}_{(\mathrm{CH}}\right)_{2}\right), 33.8$ (C-3), $44.3(\mathrm{C}-6), 52.2\left(\mathrm{COOCH}_{3}\right), 64.8(\mathrm{C}-2), 71.6\left(\mathrm{CHCH}\left(\mathrm{CH}_{3}\right)_{2}\right), 115.7\left(\mathrm{CHCH}_{2}\right), 142.3\left(\mathrm{CHCH}_{2}\right), 174.6(\mathrm{C}=0)$.

(-)-(2R)-2-Ethylpiperidine hydrochloride (8) and (+)-(2S)-2-Ethylpiperidine hydrochloride (9). A catalytic amount of $\mathrm{Pd}(\mathrm{OH})_{2} / \mathrm{C}$ (25 mol \%) was added to a solution of the corresponding 1-(1-phenylethyl)-2vinylpiperidine $7 \mathbf{a}$ or $\mathbf{6 b}(0.5 \mathrm{mmol})$ in dry $\mathrm{MeOH}(15 \mathrm{~mL})$ and the mixture was stirred under $\mathrm{H}_{2}(2.5 \mathrm{~atm})$ for 15 $\mathrm{h}$ at $\mathrm{rt}$. Then, the mixture was filtered through a short plug of Celite (eluent $\mathrm{MeOH}$ ) and concentrated $\mathrm{HCl}(0.1$ $\mathrm{mL}$ ) was added to the solution and the mixture was stirred at $\mathrm{rt}$ for $1 \mathrm{~h}$ after which the solvent was removed in vacuo obtaining the piperidine 8: colorless solid, $69 \mathrm{mg}, 92 \%$ yield, $[\alpha]_{\mathrm{D}}^{20}-1.38(c 0.5, \mathrm{MeOH}), \mathrm{lit}^{48}[\alpha]_{\mathrm{D}}^{23}-1.42$ (c 1.8, MeOH), lit. ${ }^{49}[\alpha]_{\mathrm{D}}^{23}-1.2$ (c 0.2, EtOH), m.p. 205-207 ${ }^{\circ} \mathrm{C}$, lit. ${ }^{48}$ m.p. $210-212{ }^{\circ} \mathrm{C}$, lit. ${ }^{49}$ m.p. $205-206{ }^{\circ} \mathrm{C}$, and piperidine 9: $66 \mathrm{mg}, 88 \%$ yield, $[\alpha]_{\mathrm{D}}^{20}+1.29$ (c 0.5, MeOH), m.p. 206-207 ${ }^{\circ} \mathrm{C} ; \delta_{\mathrm{H}}\left(600 \mathrm{MHz}, \mathrm{CDCl}_{3}\right) 1.05(\mathrm{t}, 3 \mathrm{H}, J$ 
7.6), $1.40-1.50(\mathrm{~m}, 1 \mathrm{H}), 1.61-1.70(\mathrm{~m}, 1 \mathrm{H}), 1.75-1.87(\mathrm{~m}, 2 \mathrm{H}), 1.89-2.01(\mathrm{~m}, 3 \mathrm{H}), 2.02-2.11(\mathrm{~m}, 1 \mathrm{H}), 2.81-2.92$ $(\mathrm{m}, 2 \mathrm{H}), 3.44-3.51(\mathrm{~m}, 1 \mathrm{H}), 9.06$ (br.s, $1 \mathrm{H}), 9.39$ (br. s, 1H). The spectroscopic data are in accordance with ref's $48,49$.

\section{Acknowledgements}

The project was financed by the National Science Centre conferred on the basis of the decision number DEC2013/09/N/ST5/02970.

\section{Supplementary Material}

Copies of ${ }^{1} \mathrm{H}$ and ${ }^{13} \mathrm{C}$ NMR spectra of the obtained compounds.

\section{References}

1. Bermejo, A.; Figadere, B.; Zafra-Polo, M.-C.; Barrachina, I.; Estornell, E.; Cortes, D. Nat. Prod. Rep. 2005, 22, 269-309.

https://doi.org/10.1039/B500186M

2. Kang, E. J.; Lee, E. Chem. Rev. 2005, 105, 4348-4378.

https://doi.org/10.1021/cr040629a

3. Daly, J. W.; Spande, T. F.; Garraffo, H. M. J. Nat. Prod. 2005, 68, 1556-1575. https://doi.org/10.1021/np0580560

4. Saleem, M.; Kim, H. J.; Ali, M. S.; Lee, Y. S. Nat. Prod. Rep. 2005, 22, 696-716. https://doi.org/10.1039/b514045p

5. Pereza, P. S.; Vallado, M. R.; Loeza, W. B.; Mena-Rejón, G. J.; Quijano, L. Fitoterapia 2000, 71, 690-692. https://doi.org/10.1016/S0367-326X(00)00152-0

6. Fodor, G.; Fumeaux, J.-P.; Sankaran, V. Synthesis 1972, 464-472. https://doi.org/10.1055/s-1972-21900

7. Bolzani, V. S.; Gunatilaka, A. A. L.; Kingston, D. G. I. Tetrahedron 1995, 51, 5929-5934. https://doi.org/10.1016/0040-4020(95)00254-6

8. Mangialasche, F.; Solomon, A.; Winblad, B.; Mecocci, P.; Kivipelto, M. The Lancet Neurology 2011, 10, 501592.

https://doi.org/10.1016/S1474-4422(11)70114-4

9. Winblad, B. Am. J. Alzheimers Dis. Other Demen. 2009, 3, 185-192. https://doi.org/10.1177/1533317509332094

10. Yerri, J.; Kotha, K. S. R.; Batchu, V, R. Tetrahedron: Asymmetry 2011, 22, 1485-1494.

11. Weston, M. H.; Nakajima, K.; Back, T. G. J. Org. Chem. 2008, 73, 4630-4637. https://doi.org/10.1021/jo800600a

12. Meguro, M.; Yamamoto, Y. Tetrahedron Lett. 1998, 39, 5421-5424. https://doi.org/10.1016/S0040-4039(98)01044-2

13. Balme, G.; Bossharth, E.; Monteiro, N. Eur. J. Org. Chem. 2003, 4101-4111. 
https://doi.org/10.1002/ejoc.200300378

14. Bajracharya, G.B.; Huo, Z.; Yamamoto, Y. J. Org. Chem. 2005, 70, 4883-4886.

https://doi.org/10.1021/jo050412w

15. Rogers, M.M.; Wendlandt, J.E.; Guzei, I.A.; Stahl, S.S. Org. Lett. 2006, 8, 2257-2260.

https://doi.org/10.1021/ol060327q

16. Davies, I.W.; Scopes, D.I.C.; Gallagher, T. Synlett 1993, 85-87.

https://doi.org/10.1055/s-1993-22359

17. Mizutani, T.; Ukaji, Y.; Inomata, K. Bull. Chem. Soc. Jpn 2003, 76, 1251-1256.

https://doi.org/10.1246/bcsj.76.1251

18. Wolfe, J.P.; Thomas, J.S. Curr. Org. Chem. 2005, 9, 625-656.

https://doi.org/10.2174/1385272053764999

19. Trend, R.M.; Ramtohul, Y.K.; Ferreira, E.M.; Stoltz, B.M. J. Am. Chem. Soc. 2005, 127, 17778-17788.

https://doi.org/10.1021/ja055534k

20. Zeni, G.; Larock, R.C. Chem. Rev. 2006, 106, 4644-4680.

https://doi.org/10.1021/cr0683966

21. Minatti, A.; Muniz, K. Chem. Soc. Rev. 2007, 36, 1142-1152.

https://doi.org/10.1039/B607474J

22. Bertrand, M.B.; Leathen, M.L.; Wolfe, J.P. J. Org. Chem. 2007, 9, 457-460.

23. Kimura, M.; Tamaki, T.; Nakata, M.; Tohyama, K.; Tamaru, Y. Angew. Chem. Int. Ed. 2008, 47, 5803-5805. https://doi.org/10.1002/anie.200801252

24. Tsuji, J.; Shimizu, I.; Minami, I.; Ohashi, Y.; Tetrahedron Lett. 1982, 46, 4809-4812.

https://doi.org/10.1016/S0040-4039(00)85719-6

25. Trost, B.M.; Krische, M.J.; Radinov, R.; Zanoni, G. J. Am. Chem. Soc. 1996, 118, 6297-6298.

https://doi.org/10.1021/ja960649x

26. Seki, M.; Mori, Y.; Hatsuda, M.; Yamada, S.-I. J. Org. Chem. 2002, 67, 5527-5536.

https://doi.org/10.1021/jo025794+

27. Gabriele, B.; Mancuso, R.; Salerno, G.; Costa, M. J. Org. Chem. 2003, 68, 601-604.

https://doi.org/10.1021/jo026532a

28. Trost, B.M.; Crawley, M.I. Chem. Rev. 2003, 103, 2921-2943.

https://doi.org/10.1021/cr020027w

29. Patil, N.T.; Yamamoto, Y. Top. Organomet. 2006, 19, 91-113.

30. Trost, B.M.; Machacek, M.R.; Aponick, A. Acc. Chem. Res. 2006, 39, 747-760.

https://doi.org/10.1021/ar040063c

31. Li, J.J.; Gribble, G. Palladium in Heterocyclic Chemistry, Pergamon Press: New York, 2000.

32. Zeni, G.; Larock, R. C. Chem. Rev. 2006, 106, 4644-4680.

https://doi.org/10.1021/cr0683966

33. Wu, X-F., Neumann, H., Beller, M. Chem. Rev. 2013, 113, 1-35.

https://doi.org/10.1021/cr300100s

34. Shaikh T. M.;. Hong, F.-E. J. Organomet. Chem. 2016, 801, 139-156.

https://doi.org/10.1016/j.jorganchem.2015.10.022

35. Zawisza, A.; Sinou, D. Tetrahedron Lett. 2006, 47, 3271-3274.

https://doi.org/10.1016/j.tetlet.2006.03.032

36. Zawisza, A.; Fenêt, B.; Sinou, D. Eur. J. Org. Chem. 2007, 2296-2309.

https://doi.org/10.1002/ejoc.200601019 
37. Olszewska, B.; Kryczka, B.; Zawisza, A. Tetrahedron Lett. 2012, 53, 6826-6829.

https://doi.org/10.1016/j.tetlet.2012.10.014

38. Olszewska, B.; Kryczka, B.; Zawisza, A. Lett. Org. Chem. 2012, 9, 563-567.

https://doi.org/10.2174/157017812802850258

39. Olszewska, B.; Szulc, I.; Kryczka, B.; Kubiak, A.; Porwański, S.; Zawisza, A. Tetrahedron: Asymmetry 2013, 24, 212-216.

https://doi.org/10.1016/j.tetasy.2013.01.012

40. Olszewska, B., Kryczka, B., Zawisza, A. Tetrahedron 2013, 69, 9551-9556.

https://doi.org/10.1016/i.tet.2013.09.043

41. Fernandez-Garcia, C.; McKervey, M. A. Tetrahedron: Asymmetry 1995, 6, 2905-2906.

https://doi.org/10.1016/0957-4166(95)00382-7

42. Enders, D.; Nolte, B.; Raabe, G.; Runsink, J. Tetrahedron: Asymmetry 2002, 13, 285-292.

https://doi.org/10.1016/S0957-4166(02)00066-6

43. Fischer, C.; Smith, S.W.; Powell, D.A.; Fu, G.C. J. Am. Chem. Soc. 2006, 128, 1472-1473. https://doi.org/10.1021/ja058222q

44. Tewes, B.; Frehland, B.; Schepmann, D.; Dina Robaa, D.; Uengwetwanit, T.; Gaube, F.; Winckler, T.; Sippl. W.; Wuönsch, B. J. Med. Chem. 2015, 58, 6293-6305.

https://doi.org/10.1021/acs.jmedchem.5b00897

45. Lood, C. S.; Laine, A. E.; Högnäsbacka, A.; Martin Nieger, M, Koskinen, A. M. P. Eur. J. Org. Chem. 2015, 3793-3805.

https://doi.org/10.1002/ejoc.201500391

46. Wang, T.; Yu, Z.; Hoon, D. L.; Phee, C. Y.; Lan, Y.; Lu, Y. J. Am. Chem. Soc. 2016, 138, 265-271. https://doi.org/10.1021/jacs.5b10524

47. Palacio, C.; Connon, S. J. Eur. J. Org. Chem. 2013, 24, 5398-5413.

https://doi.org/10.1002/ejoc.201300451

48. Andrés, J. M.; Herráiz-Sierra, I.; Pedrosa, R.; Párez-Encabo, A. Eur. J. Org. Chem. 2000, 1719-1726. https://doi.org/10.1002/(SICI)1099-0690(200005)2000:9<1719::AID-EJOC1719>3.0.CO;2-R

49. Etxebarria, J.; Vicario, J. L.; Badía, D.; Carrillo, L. Tetrahedron 2007, 63, 11421-11428.

https://doi.org/10.1016/i.tet.2007.08.067

50. Fox, D. N. A.; Gallagher, T. Tetrahedron 1990, 46, 4697-4710.

https://doi.org/10.1016/S0040-4020(01)85590-3 